\title{
Cellulose Microfibril Angle in Wood and Its Dynamic Mechanical Significance
}

\author{
Tamer A. Tabet and Fauziah Abdul Aziz
}

Additional information is available at the end of the chapter

http://dx.doi.org/10.5772/51105

\section{Introduction}

The orientation of the cellulose microfibrils in the $S_{2}$ layers of the cell walls of softwood has a significant influence on the mechanical properties of wood. The angle between the cellulose fibrils and the longitudinal cell axis, the microfibril angle, MFA was found to be a critical factor in determining the physical and mechanical properties of wood (Cave, 1997). For this reason, considerable effort has been directed towards the measurement of the cellulose MFA. Direct measurement of MFA has been made by highlighting microfibrils in individual cell walls with iodine staining, but the most widely adopted techniques use either wideangle X-ray diffraction or small-angle X-ray scattering The pioneering work of Cave (1966) and Meylan (1967) led to the use of the ' $T$ ' parameter derived from the curve distribution of the intensity diffracted by the (002) planes of the cellulose fibrils.

MFA has been found to influence shrinkage of wood (Harris and Meylan, 1965). The MFA of the $S_{2}$ layer in the tracheid cell wall is known to be one of the main determinants of the mechanical properties of wood (Cave, 1968). Donaldson (1993) reported that the MFA also had a significant impact on paper properties. The MFA has a very strong influence on the stiffness of wood (Walter and Butterfield, 1996). MFA in the $S_{2}$ layer of the cell wall of Picea abies has been to influence on cambial age and growth conditions (Hakan et al., 1998).

\subsection{Problem and background}

Much of the future timber supply in Malaysia is expected to come from Acacia mangium and hybrid Acacia wood grown in managed plantations or from small diameter logs removed during forest management operations. The short age rotation resource will contain higher properties of Acacia mangium wood compared to the present resource. Little if any, comprehensive study has been carried out in Malaysia to examine and compare the 
microstructure of wood and wood quality traits such as microfibril angle (MFA), fibre length, lumen area, surface roughness, mechanical, physical and nanostructural properties in Acacia mangium wood. In anticipation of this raw material resource, definitive information is needed on the influence of growth age one the pure crystalline cellulose and the influence of MFA on the mechanical and physical properties of lumber, so that selection and utilization methods can be adjusted sentence structure, accordingly. The angle between the cellulose fibrils and the longitudinal cell axis (MFA) was found to be a crucial factor in determining the mechanical properties of wood (Cave, 1989; Cave and Walker, 1994; Reiterer et al. 1999). The traditional methods for determining the mechanical and physical properties of wood are time consuming and tedious therefore, there is little information on microstructure of Acacia mangium wood. A much more rapid method of determining mechanical properties, MFA, moisture content and nanostructure of wood is needed.

\subsection{Wood microstructure}

The primary structural building block of wood is the tracheid or fibre cell. Cells vary from 16 to 42 microns in diameter and from 870 to 4000 microns long. Thus, the cubic centimeter of wood could contain more than 1.5 million wood cells. When packed together they form a strong composite. Each individual wood cell is even more structurally advanced because it is actually a multilayered, closed-end tube (Fig. 1) rather than just a homogeneous-walled, nonreinforced straw. Each individual wood cell is even more structurally advanced because it is actually a multilayered, closed-end tube (Fig. 1) rather than just a homogeneous-walled, nonreinforced straw. Each individual cell has four distinct cell wall layers (Primary, $S_{1}, S_{2}$, and $S_{3}$ ). Each layer is composed of a combination of three chemical polymers: cellulose, hemicellulose, and lignin (Fig. 1). The cellulose and hemicellulose are linear polysaccharides (i.e., hydrophilic multiple-sugars), and the lignin is an amorphous phenolic (i. e., a threedimensional hydrophobic adhesive). Cellulose forms long unbranched chain and hemicellulose forms short branched chains. Lignin encrusts and stiffens these polymers. Because carbohydrate and phenolic components of wood are assembled in a layered tubular or cellular manner with a large cell cavity, specific gravity of wood can vary immensely. Wood excels as a viable building material because the layered tubular structure provides a large volume of voids (void volume), it has an advantageous strength-to-weight ratio, and it has other inherent advantages, such as corrosion resistance, fatigue resistance, low cost, and ease-of modification at the job site.

\subsection{Acacia mangium}

Acacia mangium is one of the major fast growing species used in plantation forestry programs throughout Asia and the pacific. It was first introduced to Sabah, Malaysia from Australia as an exotic species in 1966. It comes from the family Leguminosae, sub-family Mimosoideae. It has rapid early growth and can attain a height of 30 meters and over $60 \mathrm{~cm}$ in diameters (Makdiken and Brewbaker, 1984). There importance as a plantation species can be attributed to a rapid growth, ruther good wood quality, tolerance to a range of soil types 
and $\mathrm{pH}$ values (Latif and Habib, 1994). Little is known about the physical and mechanical properties of Acacia mangium wood in general.

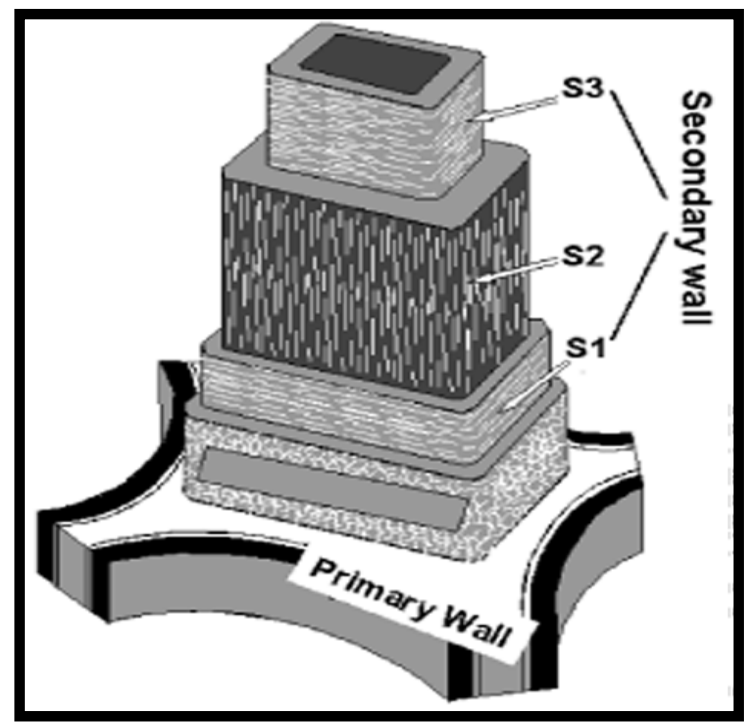

Figure 1. Layers of mature cell 1l. Source: Meylan (1972).

\subsection{Wood quality}

Wood quality results largely from the chemical and physical structure of the cell walls of its component fibres. It can be defined in terms of attributes that make it valuable for a given end use (Jozsa and Middlleton, 1994). In general, density and MFA are indicators of strength and stiffness respectively. They are reputed to be the key determinants of wood quality. For the sawmiller, wood quality is reflected in the value of mill production and this depends on grade out-turn and the value for each grade (Addis Tsehaye et al.,1995). Wood quality for the structural engineer means wood with a high stiffness level, an attribute which is most important for beams, joists and purlins. Strong wood is required for studs and trusses (Addis Tsehaye et al., 1995). For the wood technologist, wood density is important, at higher timber strength and greater yield of pulp (Elliot, 1970). The paper and pulp mill requirements for quality wood are long fibre length with low lignin content (Zobel, 1961). A minimum fibre length of $2 \mathrm{~mm}$ is necessary to produce acceptable kraft pulp. A reduction in lignin content leads to a considerable savings during the production of bleached kraft pulp (Walker and Butterfield, 1996). The most important parameters of kraft pulping are basic density and fibre length (Cown and Kibblewhite, 1980).

\subsection{Chemical composition of wood}

Wood material is primarily composed of three organic polymeric components, namely:cellulose, hemicelluloses and lignin. They primarily determine the chemical and physical 
properties of wood. Minor amounts of mainly organic inclusions are present collectively called extractives, which are present in wood but are not structural components. The amount of extractives such as gums, fats, resins, sugars, oils, starches, alkaloids and tannins, varies from less than $1 \%$ to more than $10 \%$ of the oven-dry weight of wood (Tsoumis, 1992).

Cellulose is the main constitutent of wood, occupying $40-45 \%$ of the dry wood substance in both softwoods and hardwoods (Watson and Dadswell, 1964). It consist of glucose $\left(\mathrm{C}_{6} \mathrm{H}_{12} \mathrm{O}_{6}\right)$ linked together to form cellulose chain molecule. The structural formula of the cellulose chain molecule is shown in Figure 2 (Cave and Walker 1994). Each glucose molecule added to the repeating unit of the molecule chain is rotated $180^{\circ}$. The number of the glucose monomers $\left(\mathrm{C}_{6} \mathrm{H}_{10} \mathrm{O}_{5}\right)$ in the cellulose chain is called the degree of the polymerization and in wood it is about 8000-10000, giving the cellulose molecules a length of 4-5 $\mu \mathrm{m}$ (Butterfield and Meylan, 1980). In wood cell walls, cellulose micromolecules are arranged into bundles consisting of a number of cellulose chain molecules called microfibrils, in which cellulose is mainly present in crystalline and in amorphous regions (Tsoumis, 1992). The crystalline regions of cellulose has been investigated by using x-ray scattering methods (Jakob et al., 1995) and atomic force microscopy (Svergun and Stuharmann, 1991).

In addition to cellulose, a number of various polysaccharides called hemicelluloses are present in wood. Hemicelluloses are formed from glucose and other six-carbon and fivecarbon sugar molecules and constitute $25-30 \%$ of the dry wood substance in softwoods and 25-35\% in hardwoods (Meylan, 1967). With regard to degree of polymerization, hemicellulosees are quite small macromolecules comparied to cellulose since they seldom have more than 150 -200 monomer units (Wilson and Archer, 1979). However, the clear distinction between cellulose and hemicelluloses is that hemicelluloses are soluble in aqueous alkali but cellulose is not.

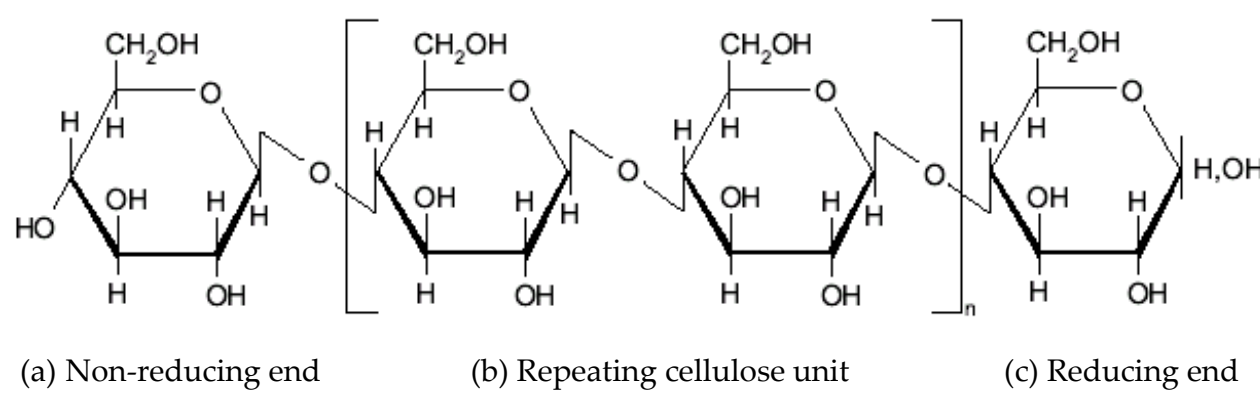

Figure 2. The structural formula of cellulose. Source: Cave and Walker (1994).

\subsection{The structure of the cell wall}

Wood cell walls are structurally complex. It is has a hollow center called lumen and layered cell walls. The cell wall can be divided into separate distinguishable layers, namely, middle lamella $(\mathrm{M})$, primary wall $(\mathrm{P})$ and secondary wall $\left(\mathrm{S}_{1}, \mathrm{~S}_{2}\right.$ and $\left.\mathrm{S}_{3}\right)$. These layers differ from one 
another with respect to chemical composition as well as their structure. The middle lamella is located between the adjacent wood cells and serves the function of binding them together. Sometimes the combine region of the middle lamela and two adjacent primary walls are called the compound middle lamella (CML), which has the most lignin rich region(Batchelor et al., 1997).

The cell wall layers are divided on the basis of how the microfibrils are arranged on the specific layers. The differences in the orientation of the microfibrils help to distiguish the primary wall and the three layers of the secondary wall from each other. The primary wall is very thin, approximately only $0.1 \mu \mathrm{m}$, and the microfibrils are randomly orientated on the outer surface and more or less transversally orientated with respect to cell axis on the inner surface near the secondary wall (Cave and Walker, 1994).

In the secondary wall, the microfibrils are closely packed and the differences in the orientation of the microfibrils are quite distinctive. The thin outer $S_{1}$ layer adjacent to the CML consist of a few lamella in which the orientation of the microfibrils have an alternating left - handed and right - handed helical arrangement, forming a crossed microfibrillar texture. In each lamela, the microfibrils spiral around the longitudinal cell axis (about $50-70^{\circ}$ ). The thickness of the $S_{1}$ layer is about $0.1-0.2 \mu \mathrm{m}$. The inner $S_{3}$ layer is usually even thinner than the $S_{1}$ layer and consist of a similar microfibrillar orientation (Cave and Walker, 1994).

The $S_{2}$ layer of the secondary cell wall is, by far, the thickest of the cell wall layers and has the most profound effect on the physical properties of wood. The microfibrils in the $S_{2}$ layer show a high degree of parallelism in all lamella with only a small dispersion and, in general, are more or less parallel to the longitudinal cell axis. Figure 3 shows the different layers of the cell wall of thin sections through Populus deltoides wood (Jean-Paul Joseleau et al., 2004). In hardwood, the microfibril angles are generally lower than in softwood species (Lichtenegger et al., 1999). The $S_{2}$ layer can reach a thickness of $5 \mu \mathrm{m}$ or more and contains, for example in softwoods, up to $80 \%$ or more of the total cell wall material (Tsoumis, 1992 and Donaldson, 1996). Therefore, the magnitude of the MFA in the $S_{2}$ layer has been considered as one of the most important elements affecting the different properties of wood. It is defined as the angle between microfibrils of the $S_{2}$ layer and the longitudinal axis of the wood cell. In general, when the MFA of wood is discussed in literature, it specifically refers to the angle of microfibrils in the $S_{2}$ layer. As the $S_{2}$ layer represents the major component of the cell wall, its MFA has a significant effect on the mechanical properties such as modulus of elasticity, strain and extensibility (Reiterer et al., 1999).

\subsection{Cellulose microfibrils}

Microfibrils are the structural units of plant cell wall. Each microfibril contains a number of cellulose chain molecules bundled together, and is surrounded by low molecular weight hemicelluloses (Tsoumis, 1992). The hemicellulose act as connecting agents that link or of bond the microfibrils together (Hygreen and Bowyer, 1996). The cellulose chain molecules are generally arranged lengthways with regard to the microfibril axis, but run parallel to each other in portions. These portions are called crystalline regions. The molecules in these 
regions are strongly connected to each other by hydrogen bonding. The crystalline regions are followed by amorphous regions in which the cellulose molecules have no definite arrangement. The transition from crystalline to amorphous region is gradual. Approximately two thirds of the cellulose in the cell wall is crystalline in form while one third is amorphous (Tsoumis, 1992). Microfibrils vary in width from $1 \mu \mathrm{m}$ in the primary walls to $10 \mu \mathrm{m}$ in the secondary walls (Zobel, 1961). The angle that the cellulose microfibril make to the axis of the cell wall is known as the microfibril angle (MFA). Microfibrils are present in each of the cell wall layers (Butterfield, 1980). The microfibrils is the smallest component of the cell wall which can be visualized by transmission electron microscopy occurring along fibril 3-4 $\mathrm{nm}$ in diameter and it consists of a group of cellulose surrounded by a sheath of hemicellulose (Harris and Meylan, 1965). The cellulose microfibrils are wound helically around the cell wall in the $S_{2}$ layer, as shown in Figure 4.
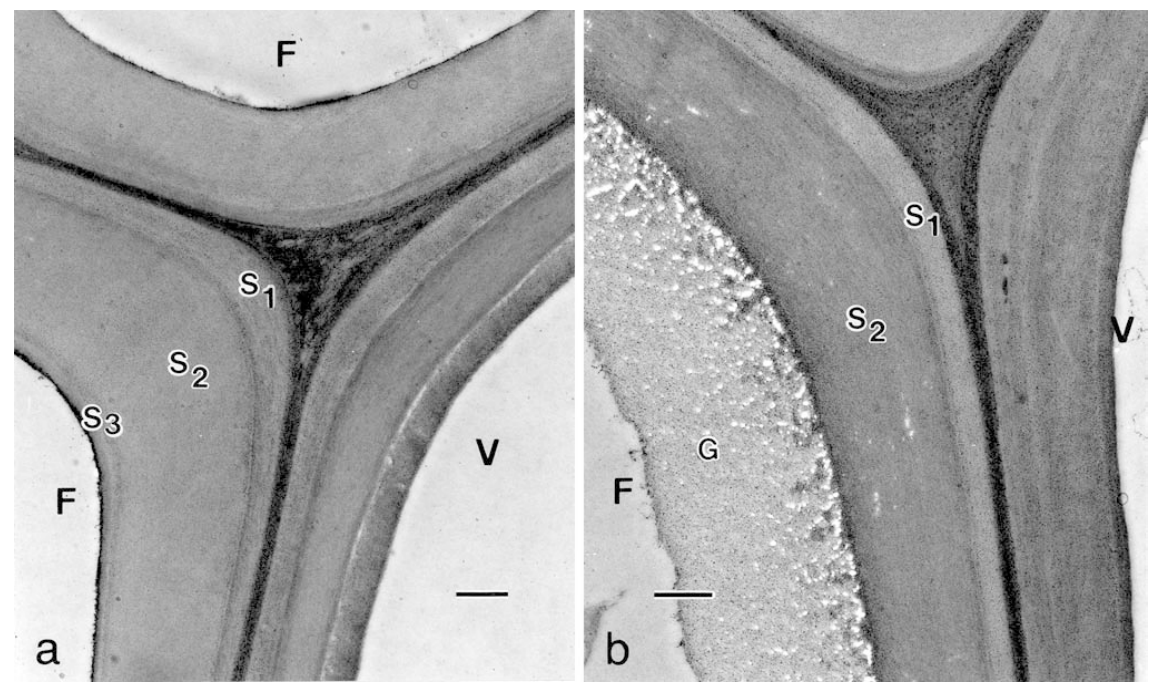

Figure 3. Transmission electron micrograph of thin sections through Populus deltoides wood. Periodicacid-thiocarbohydrazide- silver proteinate (PATAg) staining. Tension wood fibre (b) has developed a gelatinous layer (G-layer) against an $S_{2}$ layer that is thinner than in normal wood fibre (a). F Fibre; V vessel; $S_{1}, S_{2}, S_{3}$ secondary wall sub-layers; G gelatinous layer. Bars $=0.5 \mathrm{~lm}$. (Jean-Paul Joseleau et al., 2004).

\subsection{Microfibril Angle (MFA)}

One of the primary importance in many investigations of the properties of natural cellulosic fibres is the knowledge of the orientation of the constituent cellulose microfibrils. The orientation of the elementary cellulose fibrils reinforcing the wood cell wall has been a subject of growing interest in recent years. Particular attention has been attracted by the tilt angle of the cellulose fibrils with respect to the longitudinal cell axis called the microfibril angle (MFA) that was found to influence the mechanical properties of wood (Cave, 1997) as well as shrinkage during drying (Meylan, 1967). MFA was also discussed with respect to 
influences on stiffness and tensile strength of fibres and paper (Cave, 1976). MFA varies from tree to tree, pith to cambium and with height in the stem. It also varies with speed of growth of the tree. Many methods, such polarizing, fluorescence and electron microscopy and iodine staining, used to estimate the MFA are tedious and time consuming because the extreme variability of biological material demands that large numbers of fibre elements be measured to give meaningful average values. In contrast, $x$-ray diffraction can provide a mean diffraction pattern of several hundred elements in a single exposure, a little cost in preparation and observation time. The main drawback to the $\mathrm{x}$-ray method has been the interpretation of the diffraction patterns in terms of microfibril distribution. Methods to measure MFA include X-ray diffraction (Cave, 1966), Wide angle x-ray scattering (Boyd, 1977), and Small-angle X-ray scattering (Jakob et al., 1994). The recently increased attention on MFA in wood has encouraged researchers to compare different measuring methods (Bertaud and Holmbom, 2004). These approaches are important, as encountered discrepancies foster new research towards a better understanding of MFA in wood.

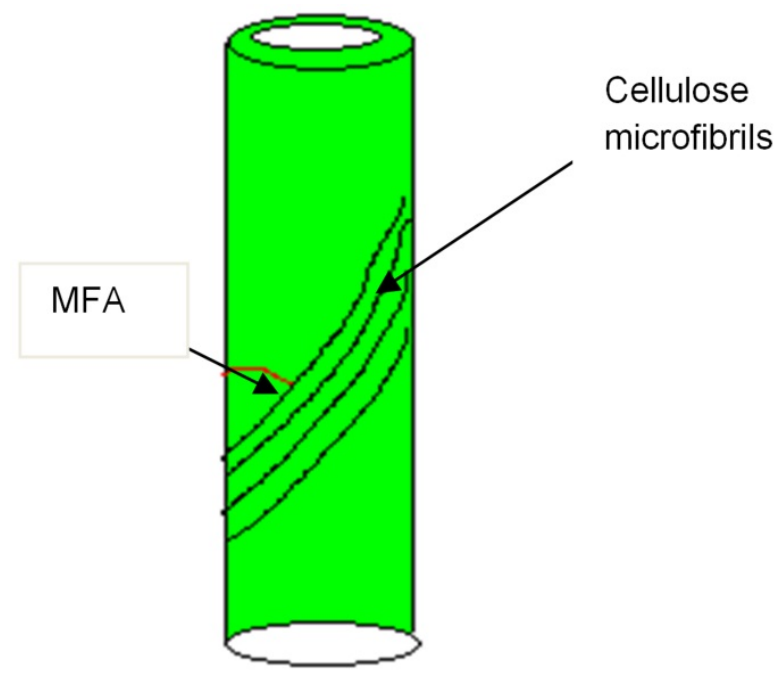

Figure 4. Cellulose microfibrils in wood cell. Source: Fratzl et al., (1997)

In the present study, $x$-ray diffraction and small-angle $x$-ray scattering techniques were used to determine MFA as a rapid technique for measuring microfibril angles in Acacia mangium wood from pith to bark. The x-ray diffraction technique used the diffraction pattern created by the interaction of x-ray with wood tissue to determine MFA. A group of fibers in the sample is irradiated perpendicular to the fibre length by a narrow, monochromatic x-ray beam. A diffraction pattern is produced by the crystalline cellulose structure and recorded by film or by an electronic detector. The average MFA was calculated using Cave (1966) method. In general, the width of (002) diffraction arc reflects the magnitude of the mean MFA and most methods in use are based on a measurement of the width of the arc. The width of the diffraction arc in the method presented here is determined by the angular 
separation, $T$, of the intercepts with the zero intensity axis of the tangents at the points of inflexion, of the outer slopes of the intensity curve of the diffraction arc. X-ray diffraction can provide a mean diffraction pattern of several hundred elements in the sample in one single exposure and it has the potential to reduce dramatically the time required to determine MFA. In order to further elucidate to the effect of MFA on the growth age, physical and mechanical properties of Acacia mangium, x-ray diffraction (XRD) and smallangle x-ray scattering (SAXS) were used in this study. The combination of XRD measurements with SAXS on the same microtome sections allowed us to establish a direct relationship between microfibril angle and wood behavior.

\subsection{Importance of MFA}

The term microfibril angle, (MFA) in wood science refers to the angle between the direction of the helical windings of cellulose microfibrils in the secondary cell wall of fibres and the long axis of the cell wall (Cave, 1966). Technologically, it is usually applied to the orientation of the cellulose microfibrils in the $S_{2}$ layer that makes up the greatest proportion of the wall thickness, since it is this which most affects the physical properties of wood (Senft Bendetsen, 1985). Figure 5 shows a confocal micrograph of wood fibre under crosspolarisers. It shows the fibre as bundle of helical wound microfibrils composing highly aligned molecules, the MFA in the $S_{2}$ layer is the angle of the microfibrils relative to the long axis of the cell wall (Cave, 1966). The MFA of the $S_{2}$ layer represent an important ultramicroscopical feature influencing the performance of wood products. It has a major effect on the stability of wood on drying and subsequent manufacturing processes (Zobel, 1961). Orientation of the $S_{2}$ MFA has a significant influence on tensile strength, stiffness and shrinkage. Modeling suggest that the relative thickness of the $\mathrm{P}, \mathrm{S}_{1}$ and $\mathrm{S}_{3}$ layers contributes significantly to the variability of longitudinal shrinkage (Cave, 1976). Both the longitudinal tensile strength and stiffness of wood have been shown to be markedly affected by MFA; as the MFA increases, tensile strength and stiffness quickly decrease (Mary Treacy et al., 2001). Long cells, with low microfibril angles, make for more stable and stronger boards, and the incidence of high MFA is one reason why juvenile wood of loblolly pine (Pinus taeda) is weak and somewhat unstable (Cave, 1997). Although other mechanical properties appear to be only slightly affected by MFA (Cave and Walker, 1994). Cave and Walker (1994) concluded that MFA was the only factor that alone could account for the pronounced decrease in stiffness of radiata pin wood. The relatively narrow range of variation in microfibril orientation in the $S_{2}$ wall layer makes it clear that broad genetic influences are involved (Boyd, 1977). Modifications to the MFA in reaction wood are well known. For example, Addis Tsehaye et al (1995) has observed the microfibril angles in the branches of Radiata pine trees to be smaller where tensile growth stresses are larger. The within-tree and between-tree variation of MFA in the $S_{2}$ layer of the secondary cell wall has attracted the attention of some researchers. Donaldson (1993) found that MFA in pinus radiata showed a curvilinear decline from pith to bark, which was more pronounced at the butt end of the stem. The angle also declined rapidly with height within the tree, reaching more or less constant values at heights above $7 \mathrm{~m}$. The tilt angle of the cellulose fibrils versus the 
longitudinal cell axis, plays an important role in determining the actual stiffness of the material (Meylan and Probine, 1969). Young's modulus in bending of clear small specimens was shown to be closely correlated with both specific gravity and MFA (Cave, 1969). In softwoods the MFA decreased from pith to to bark, there is no consistent explanation for the differences in MFA within a single stem (Preston, 1934). The MFA has already been the subject of extensive investigations (Jakob et al., 1994).

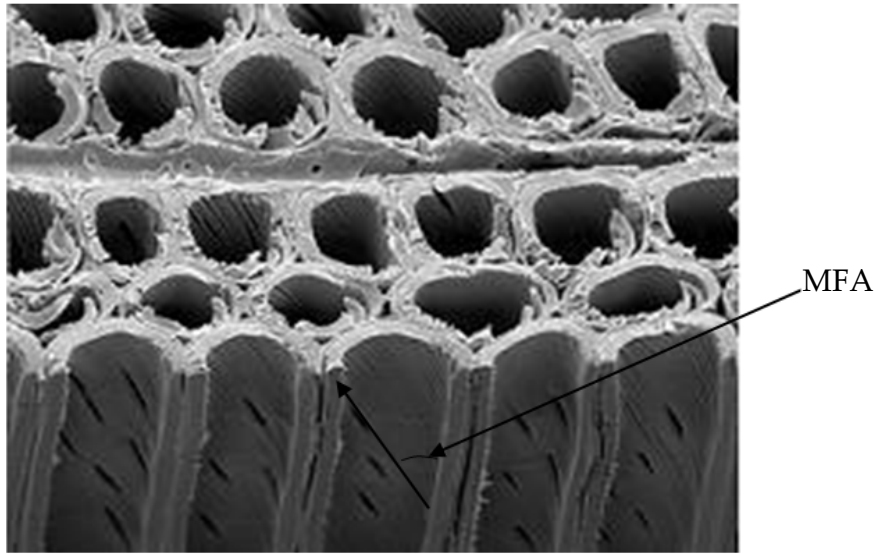

Figure 5. SEM micrograph showing the microfibrils in the $S_{2}$ layer of Norway spruce wood sample. Seppo Andersson , 2007.

\subsection{Environmental impacts on MFA}

Growth rate influences MFA in two ways. Firstly, fast growing trees have the largest microfibril angles both in juvenile and mature wood, and secondly, narrow growth rings are formed in some trees when they are suppressed and these rings tend to have tracheids with a large MFA (Brändström, 2002). The results of a trial carried out by Mary et al., (2001) suggest that fast growth may lower the quality of juvenile wood in Sitka spruce. Bergander et al. (2002) reported that in a comparison of slow-grown versus fast-grown Norway spruce, a significant increase of the $S_{2}$ MFA was demonstrated in the fast grown spruce. This may change the quality of wood as well as the strength properties of pulp and paper produced from it.

\subsection{Methods of measuring MFA}

There are essentially four methods for measuring MFA in the cell wall: X-ray diffraction (Cave, 1966; Boyd, 1977), polarized light microscopy (Meylan, 1969; Evans, 1999), direct or indirect observation (Senft and Bendtsen, 1985; Donaldson,1991) and small angle X-ray scattering ( SAXS), (Jakob et al., 1995; Reiterer et al. 1998; Lichtenegger et al. 1999).

X-ray diffraction is the fastest and most modern method of measuring the MFA. This method enables large sample numbers to be measured in a short time. It has been used to 
determine MFA (Cave ,1966; Harris and Meylan, 1965; Meylan,1967). Evans (1999) used XRD technique for determining the MFA in Eucalyptus. Further studies using x-ray diffraction from the 002 as well as the 040 planes of cellulose in wood were carried out by Nomura and Yamada (1972). In this technique, a thin section of wood is irradiated perpendicular to the fibre length by X-ray beam producing a set of diffraction patterns. This pattern consist of a series of arcs that are spaced apart by a number of well-defined concentric circles. The diameters of the concentric circles are indications of the spacing of the crystalline planes with the cellulose crystalline fibrils. Reflections arising from cellulose crystall planes of the type $(0 \mathrm{~K} 0)$ give the MFA distribution directly, but generally these reflections are too weak or too poorly resolved to be used and one is forced to use the very strong (002) reflection. Evaluation of the mean MFA then involves an assumption of the form of the microfibril distribution. The angular distance from the equator to the point where the tangent at the point of inflection of the intensity curve cuts the zero intensity axis is $T$ (Cave, 1966). The width $T$ has been shown to be correlated to the MFA (Meylan, 1967).

\subsection{The parameter $T$}

In general, the width of the (002) diffraction arc reflects the magnitude of the mean MFA and most methods in use are based on a measure of the width of the arc (Cave, 1966). The width of the diffraction arc in the method presented here is determined by the angular separation, $T$, of the intercepts with the zero intensity axis of the tangents at the points of inflexion, of the outer slopes of the intensity curve of the diffraction arc as shown in Figure 6. The choice of this measure was made originally on practical grounds, but the present study provides further justification by using Scanning Electron Microscope (SEM.

\subsection{Angular distribution of microfibrils}

The theoretical relation between $T$ and the mean MFA is obtained by considering the relationship between the shape of the angular distribution of the microfibrils in the plane of the cell wall and the shape of the intensity distribution of the (002) arc. The shape of the intensity distribution is also dependent to some degree on the cross-sectional shape of the cells.

Tracheids may vary in shape from rectangular through irregular hexagonal to circular. The theory considers two extreme shapes, square and circular, in order to indicate the likely effect of cell cross-sectional shape on the diffraction diagram (Cave, 1966). Wherever possible, a general angular distribution of microfibrils has been assumed in the plane of the cell wall, subject to the following conditions:

i. The microfibril is essentially a single crystall.

ii. All microfibrils are crystallographically identical

iii. The cell wall consist of a single homogeneous layer of microfibrils called $S_{2}$ layer embedded in a noncrystalline matrix. 
iv. The microfibrils lie strictly in the plane of the cell wall (Cave, 1976). e angular distribution of microfibrils in the plane of the wall. This taken to be approximately that of the normal probability function with a mean MFA, and standard deviation $\sigma$ (provided $\sigma \leq 30^{\circ}$ ) (Meylan, 1972)

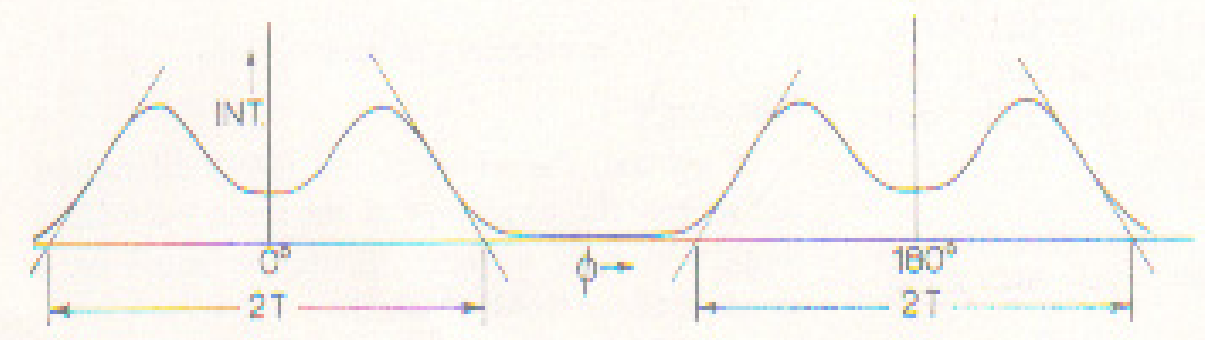

Figure 6. Schematic graph record around the (002) reflection circle of wood showing tangents drawn at the points of the inflexion in the measurement of the parameter T. Source: Cave (1966).

\section{Materials and methods}

The wood samples used in this study were selected from 3, 5, 7, 9, 10, 11, 13 and 15 year-old of Acacia mangium tree from Sabah Forestry Development Authority (SAFODA) and Ganui Plantations, Sabah, Malaysia. The standard methodology for the physical characterization followed the International technical standard (ISO standard 4471-1982). The samples were taken out at breast height $(1.25 \mathrm{~m})$ on each tree. An x-ray diffractometer (Philips X-Pert PRO PW3040/60) was used to determine the average microfibril angle. A point-focused $x$-ray beam $(\mathrm{Cu}-\mathrm{K} \alpha \mathrm{x}$-ray, beam diameter $1 \mathrm{~mm}$ ) was applied to tangential section, $200 \mu \mathrm{m}$ thick $\mathrm{x}$ $2 \mathrm{~mm}$ long, prepared from the pith and bark regions with a sliding microtome as shown in Figure 7. The measurements were made at a speed of 6 degrees per minute, at a Bragg's angle $22.4^{\circ}$, using the $2 \mathrm{~mm}$ diverging slit and $1 \mathrm{~mm}$ receiving slit. A diffraction pattern is produced by the crystalline structure and recorded by an electronic detector. Parameter $T$ defined by Cave, was obtained from the diffraction intensity around (002) arc [3]. Three lines were drawn to derive half the width of the curve. The first was the baseline representing the portion in the curve when the x-ray intensity was more or less minimal. Then, a tangent was drawn to divide the curve in to two equal parts.

Radial slices $50 \mu \mathrm{m}$ thick were cut by rotary microtome from each trunk and then used for Probe microscope.

Samples for Dynamic Mechanical Analyzer DMA testing were prepared using a table saw. They were further machined down to nominal thickness of $3.0 \mathrm{~mm}$ using vertical milling machine. The samples were held in place under controlled humidity and temperature. Care was taken to obtain samples from the same area of the impact region in the wood trunk. Each disc of wood was machined to produce a balance DMA samples desired thickness. The final samples dimensions were $50 \mathrm{~mm} \times 13 \mathrm{~mm} \times 3 \mathrm{~mm}$. 


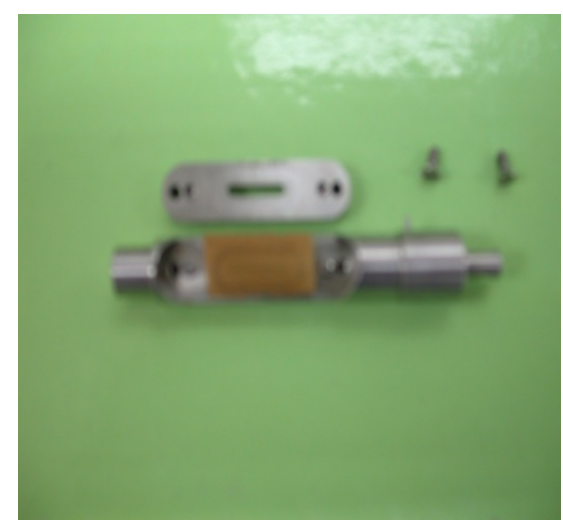

(a)

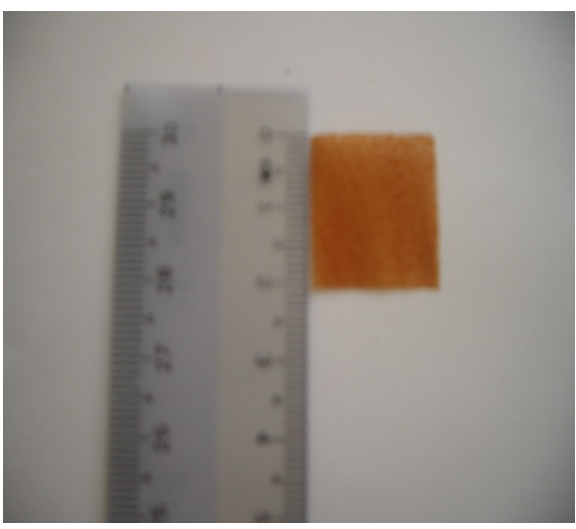

(b)

Figure 7. (a) Sample holder of SAXS machine with wood strip. (b) Wood strip.

\section{Determining of MFA}

Methods to determine the mean microfibril angle, MFA, crystallinity of wood and the average size of cellulose crystallites were presented. The mean MFA, the crystallinity of wood and the size of the cellulose crystallites were determined as a function of the tree age in Acacia mangium wood found in Sabah.

\subsection{Calculation of Microfibril Angle (MFA) Using X-Ray Diffraction (XRD)}

Microfibril angle, MFA can be defined as the angle between tracheid or fibre axis and microfibril orientation in the $S_{2}$ layer. Evaluation of the mean MFA then involves an assumption of the form of the microfibril distribution. It is of interest to examine the differences of the intensity distributions diffracted between the different ages of the real cell wall structure. We can clearly observe the change in the diffraction pattern with increasing the tree age. Figure 14 schematically represents thin sample of wood, which has a rectangular cross-section. The fibre axis or the cell axis is vertical towards the radial direction of the tracheid, which represent the surface of the paper (Figure 8). Two cellulose MFA ( $Z$ helix) have been drawn, one in the front cell wall and the other on the back cell wall. When the MFA is determined using x-ray diffraction and a slice of wood, both the front and back cell wall contribute to the intensity curve (Figure 8).

The models, which will be presented in this study, related primarily to studies of wood cell wall structure. An SEM micrograph of a cell wall from Acacia mangium wood of age 15-yearold is shown in Figure 8. The model of the cellular geometry shows the microfibrils bundle together in the cell wall, this will subsequently be translated in to a finite element in which each cell wall division as sketched in Figure 9. The orientation of the microfibrils in cell wall layers is illustrated in Figure 10. 


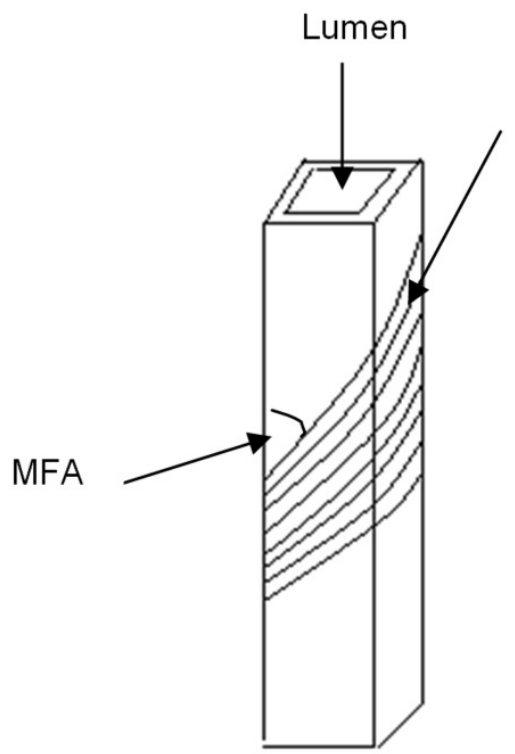

Microfibrils wound

helically

- MFA

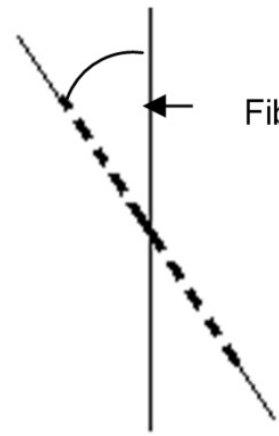

+MFA

ibre axis

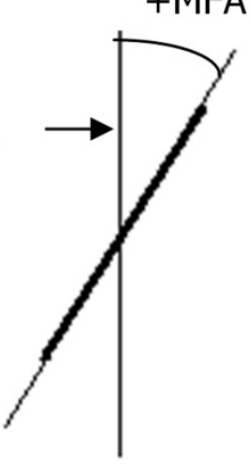

Figure 8. Schematic diagram represents the rectangular cross section of wood sample and the orientation of the cellulose microfibrils in both front, +MFA and back, -MFA around the fibre axis (Drawing not to scale).

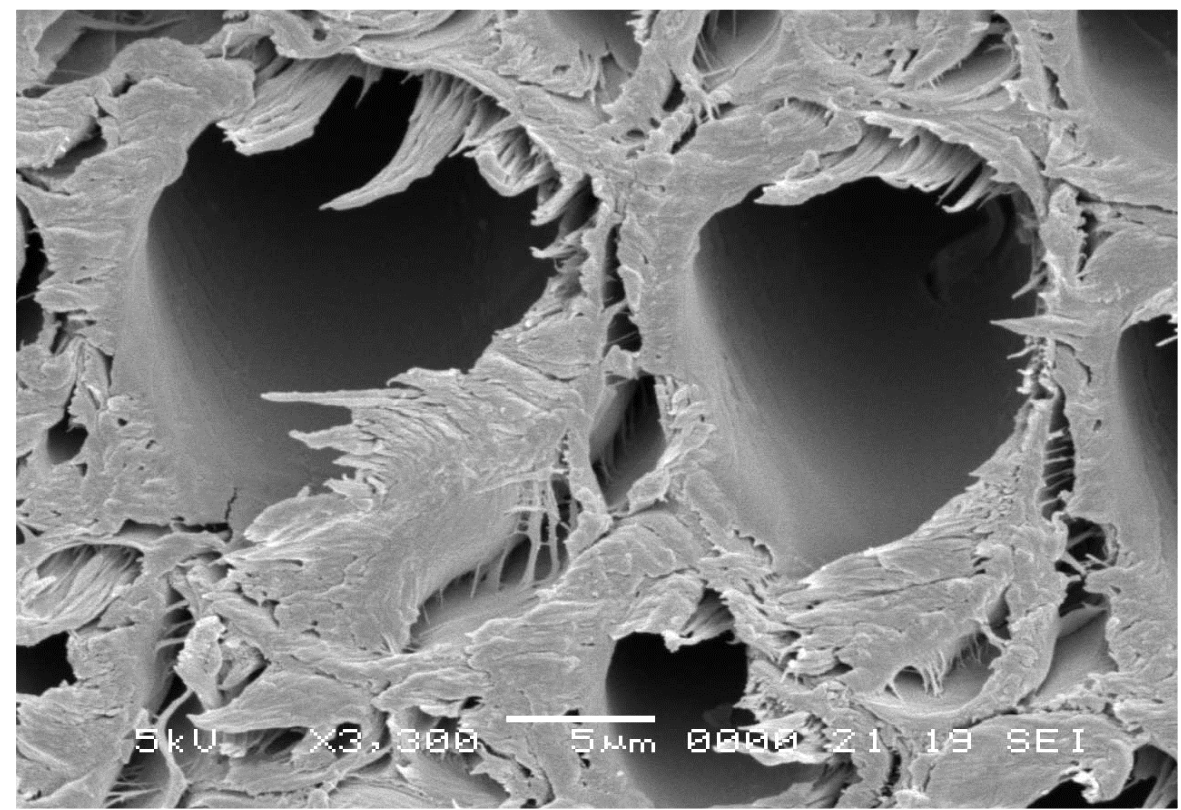

Figure 9. SEM micrograph, X 3300 showing the structure of cell wall Acacia mangium wood sample from age 15 year old. 

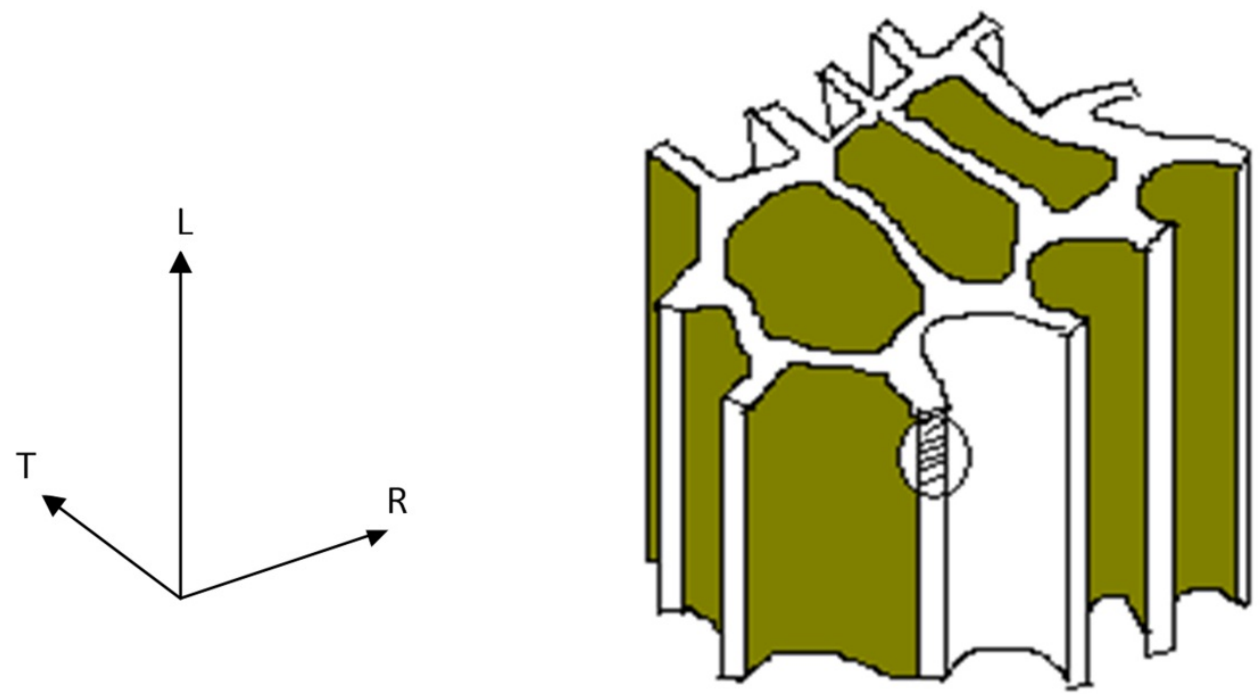

Figure 10. Schematic diagram showing model of the cellular geometry of the cell walls, at radial (R), tangential $(\mathrm{T})$ and longitudinal direction $(\mathrm{L})$.

Figure 11, shows typically diffraction pattern arising from the pith region of Acacia mangium wood as a slice samples of thickness $200 \mu \mathrm{m}$ from growth age 15 year-old. The MFA is determined from the intensity that has the strongest peak (Andersson, 2006). In this work, the intensity peak at $2 \theta \approx 22^{\circ}$ has been used to calculate the parameter $T$ for all growth ages because the peak of the diffraction intensity gives the best Full Width Half Maximum, FWHM value in this case. In case of wood sample from 15-year-old tree. The intensity peak at $2 \theta=22.11^{\circ}$ gives FWHM about $0.02^{\circ}$ was used to calculate the MFA for the wood sample of 15-year-old (Figure 11).

The parameter $T$ was used as an indicator to MFA. $T$ was calculated using Cave method (1966). Mean MFA was calculated using the formula developed by Yamamoto et al., (1993). Three lines were drawn to derive half the width of the curve. The first was the baseline representing the portion in the curve where the X-ray intensity was more or less minimal. Than, a tangent was drawn through the inflection point on one side of the curve. Finally a vertical line was drawn to divide the curve in to two equal parts as shown in Figure 12. The results shows that the MFA ranged from $26.13^{\circ}$ at the pith region of Acacia mangium wood at age 3 year-old, and decreases to about $0.20^{\circ} \pm 0.01^{\circ}$ at tree age 15 year-old. It was found that the mean MFA at the bark region of Acacia mangium wood behaves the same way. MFA and standard deviation for Acacia mangium from 3 year-old at bark region was calculated using the polynomial relationship of Yamamoto et al., (1993).

$$
M F A=1.575 \times 10^{-3} T^{3}-1.431 \times 10^{-1} T^{2}+4.693 T-36.19
$$

$T=2.3^{\circ} \pm 0.1^{\circ}$ for growth age of 3-year-old as shown in Figure 4.9. 


$$
M F A=-26.13^{\circ}
$$

The (-) signal mean that the microfibrils orient in the back cell wall.

The parameter $T$ given by Cave (1966) by the formula:

$$
\begin{gathered}
T=M F A+2 \sigma \\
\sigma=14.21^{\circ}
\end{gathered}
$$

Where $\sigma=14.21^{\circ}$ represent the standard deviation of the intensity distribution arising from the fibril orientation about the mean value.

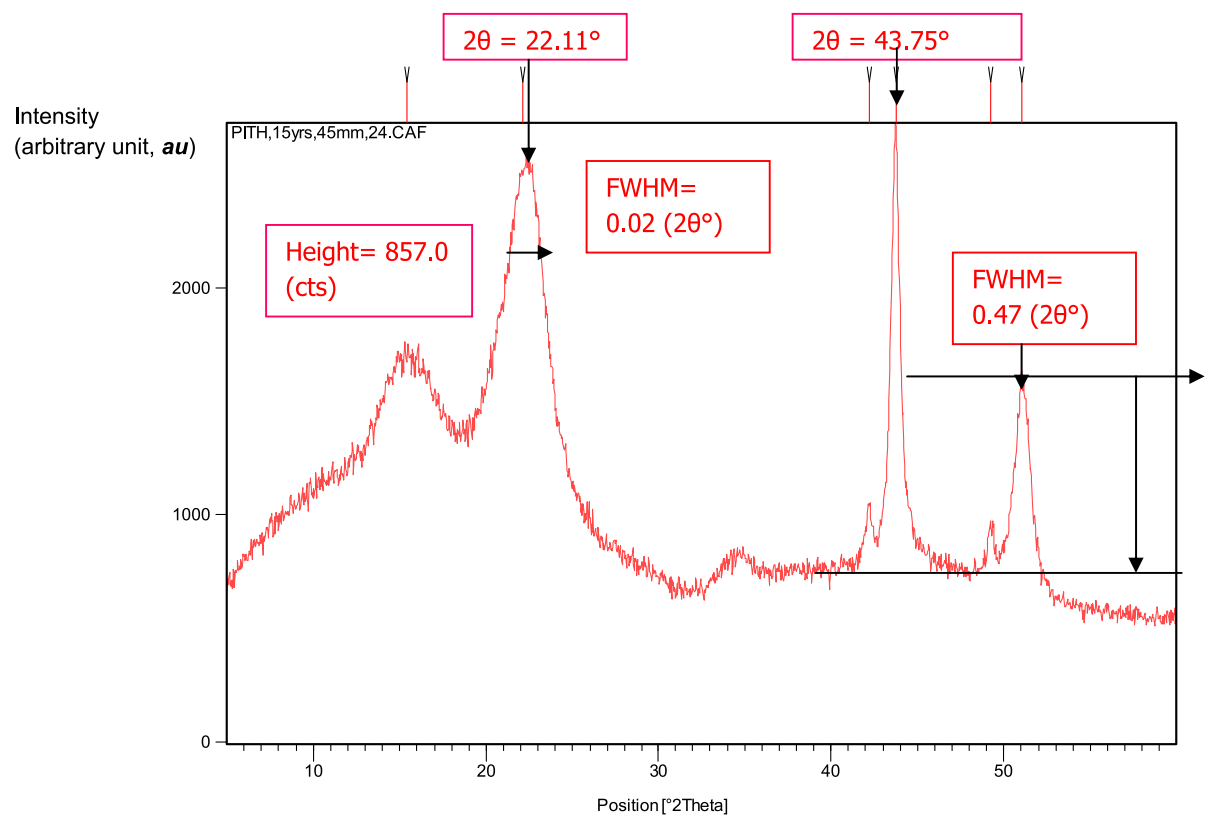

\begin{tabular}{|c|c|c|c|c|c|}
\hline No. & Position $2 \theta^{\circ}$ & Height (cts) & FWHM $\left(2 \theta^{\circ}\right)$ & d-spacing $(\AA)$ & Intensity $(\%)$ \\
\hline 1 & 15.4327 & 538.24 & 1.3815 & 5.74173 & 28.75 \\
\hline 2 & 22.1110 & 857.00 & 0.0200 & 4.02033 & 45.78 \\
\hline 3 & 42.2004 & 245.80 & 0.2598 & 2.14149 & 13.13 \\
\hline 4 & 43.7580 & 1871.92 & 0.3247 & 2.06881 & 100.00 \\
\hline 5 & 49.2453 & 209.82 & 0.3247 & 1.85037 & 11.21 \\
\hline 6 & 51.0608 & 872.48 & 0.4752 & 1.78728 & 46.61 \\
\hline
\end{tabular}

Figure 11. Typical diffracting pattern arising from pith region with peak list of Acacia mangium wood of 15-year-old. 


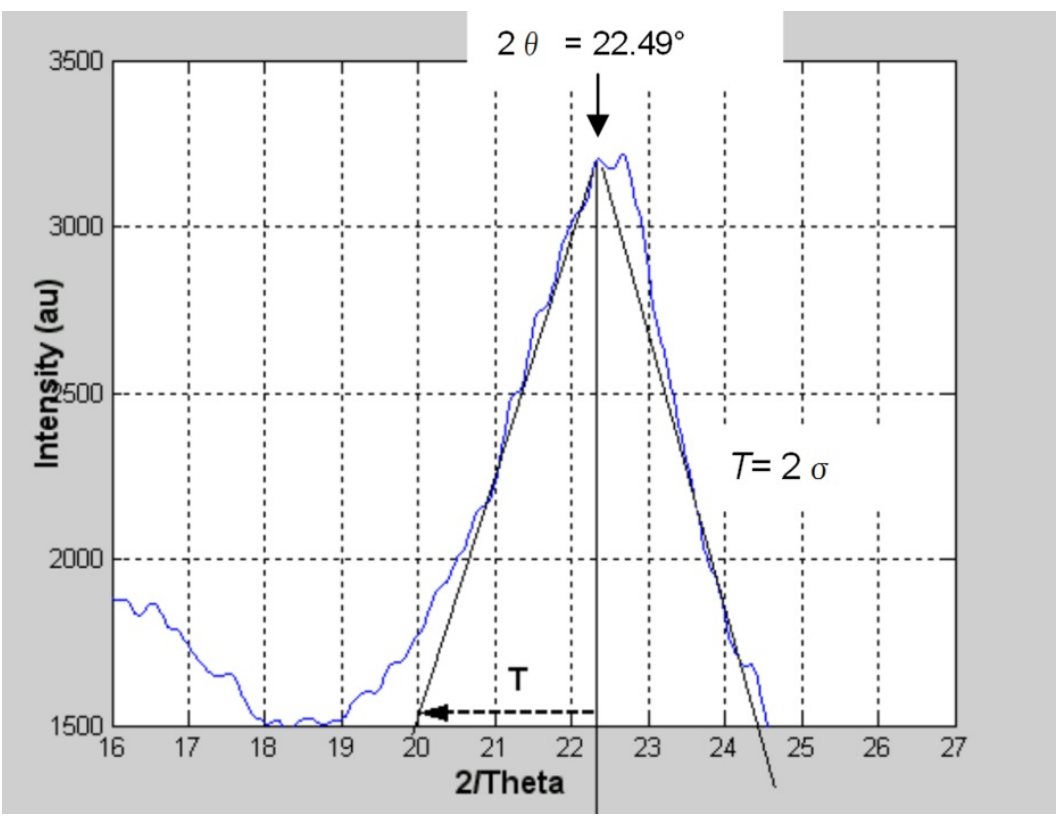

Figure 12. X-ray diffraction intensity used to determine the parameter $\mathrm{T}$ in wood model of 3 year-old.

Figure 13 shows SEM micrograph for the wood slice of thickness $50.0 \mu \mathrm{m}$ taken from the pith region of Acacia mangium tree of age 3 year old.

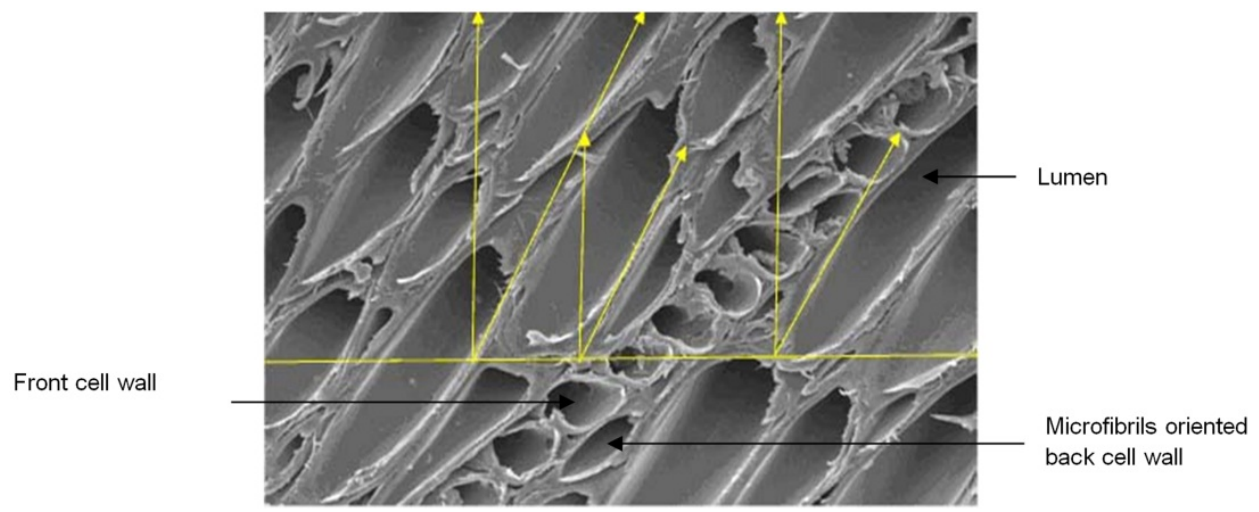

Figure 13. SEM micrograph at magnification $\times 2000$ showing the orientation of microfibrils in the bark region of wood sample at age 3 year old. 


\section{Results}

MFA decreased as the tree age increase. most significant drop occurring from $21.45^{\circ}$ at age 5 year-old to $16.14^{\circ}$ at age 7 year-old, and from $9.80^{\circ}$ at 10 year old to $4.96^{\circ}$ at 11 year old at the pith region. The smallest value of MFA was found in the pith center, MFA $=0.20^{\circ} \pm$ $0.01^{\circ}$. An inverse relationship between MFA and tree age was evident in this study within the pith region (Figure 14). The MFA of Acacia mangium in the bark region behaves the same way. The highest rate of decreasing of MFA occurring between ages 5 to 7 year old within the bark region. MFA was found to drop from $27.36^{\circ}$ at 5 year old to $17.83^{\circ} \pm 0.01^{\circ}$ at age 7 year old. An inverse relationship between tree age and MFA was found within the bark region (Figure 15). Tables 1 and 2 are shows the values of the MFA and the standard deviation $\sigma$ for each age of Acacia mangium tree in pith and bark regions respectively.

\begin{tabular}{|c|c|c|c|c|}
\hline Sample No. & Tree age (year) & MFA $\mathbf{\pm 0 . 0 1 ^ { \circ }}$ & $\boldsymbol{\sigma} \mathbf{(}^{\circ}$ ) & $\begin{array}{c}\text { Microfibrils } \\
\text { orientation }\end{array}$ \\
\hline 1 & 3 & 26.13 & 14.21 & Back cell wall \\
\hline 2 & 5 & 21.45 & 8.97 & Back cell wall \\
\hline 3 & 7 & 16.14 & 5.47 & Back cell wall \\
\hline 4 & 9 & 11.30 & 2.40 & Back cell wall \\
\hline 5 & 10 & 9.80 & 1.40 & Back cell wall \\
\hline 6 & 11 & 4.96 & 4.27 & Front cell wall \\
\hline 7 & 13 & 0.26 & 0.08 & Front cell wall \\
\hline 8 & 15 & 0.20 & 0.07 & Front cell wall \\
\hline 9 & 15 (Pith center) & 0.20 & 0.07 & Front cell wall \\
\hline
\end{tabular}

Table 1. The values of the MFA and the standard deviation $\sigma$ in the pith region for each age of Acacia mangium tree.

\begin{tabular}{|c|c|c|c|c|}
\hline Sample No. & Tree age (year) & MFA $\pm \mathbf{0 . 0 1}^{\circ}$ & $\boldsymbol{\sigma} \mathbf{(}^{\circ}$ ) & $\begin{array}{c}\text { Microfibrils } \\
\text { orientation }\end{array}$ \\
\hline 1 & 3 & 31.62 & 15.13 & Back cell wall \\
\hline 2 & 5 & 27.36 & 12.68 & Back cell wall \\
\hline 3 & 7 & 17.83 & 6.60 & Back cell wall \\
\hline 4 & 9 & 14.44 & 4.47 & Front cell wall \\
\hline 5 & 10 & 9.87 & 1.43 & Front cell wall \\
\hline 6 & 11 & 5.67 & 1.42 & Front cell wall \\
\hline 7 & 13 & 3.17 & 3.16 & Back cell wall \\
\hline 8 & 15 & 0.47 & 0.15 & Back cell wall \\
\hline
\end{tabular}

Table 2. The values of the MFA and the standard deviation $\sigma$ in the bark region for each age of Acacia mangium tree. 


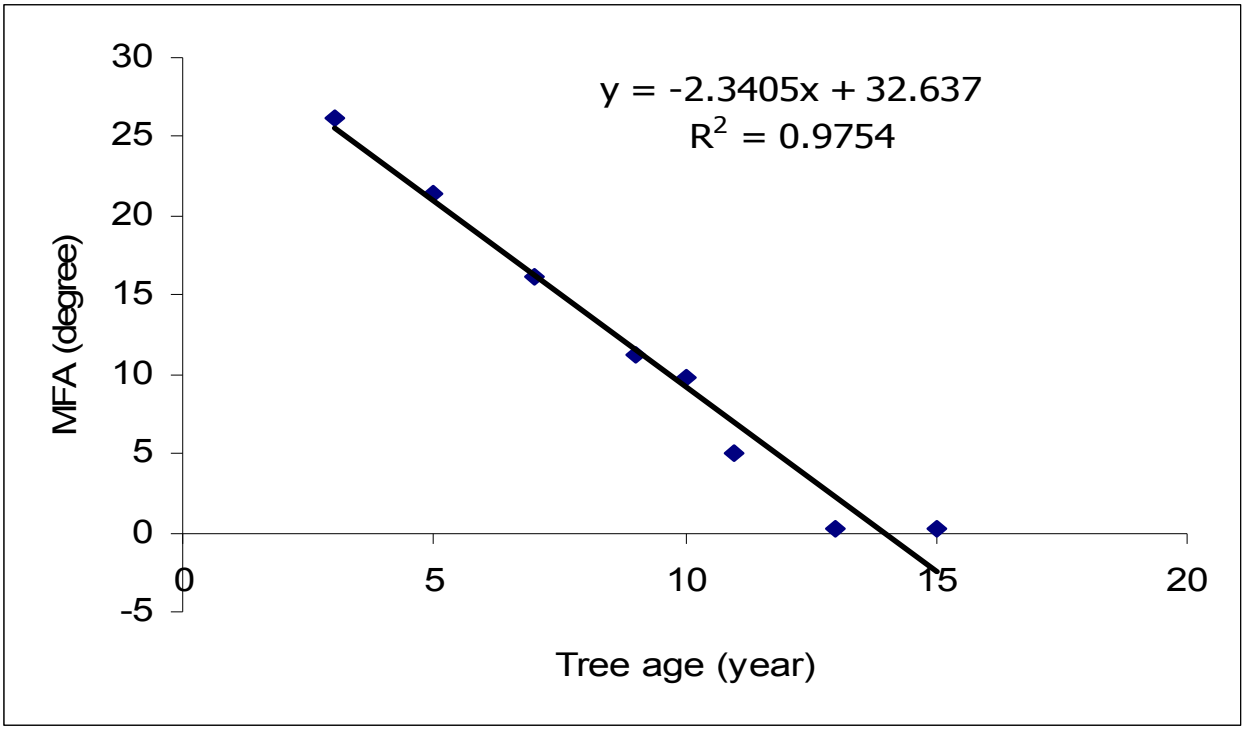

Figure 14. The relationship between MFA and the tree age in the pith region of Acacia mangium wood.

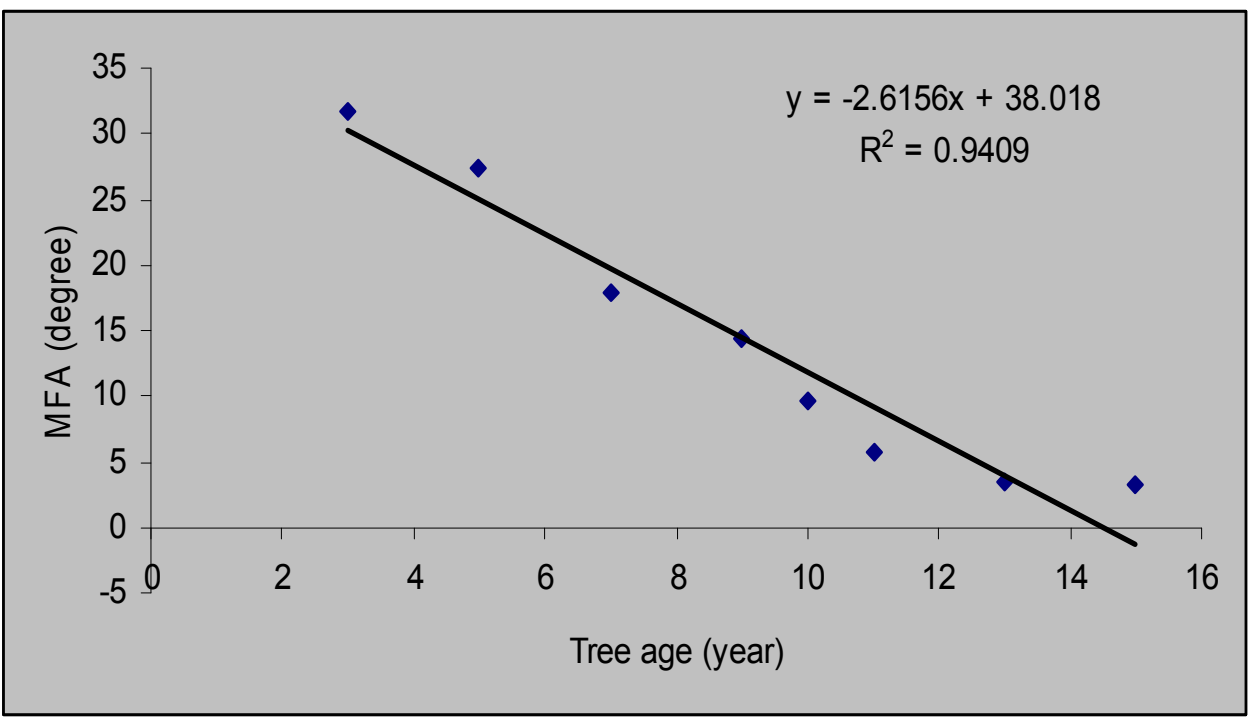

Figure 15. The relationship between MFA versus tree age in the bark region of Acacia mangium wood.

\section{Thermal and dynamic-mechanical properties of wood}

The complicated hierarchical and cellular structure of wood is well known to provide excellent mechanical properties such as stiffness and strength. Wood represents a natural 
composite with the ability to adapt its structural properties to external mechanical requirements in all hierarchical levels (Cave, 1997a). In the microscopic and nanoscopic scale, the structural optimization of the mechanical behavior of wood is closely related to the cell wall microstructure. The mechanical properties of wood are known to be greatly influenced by its anatomical structure (Boyd, 1977). It is well known that the stiffness of wood is mostly given by the semi-crystalline cellulose microfibrils.

Thermal analysis has been extensively applied to investigate the thermal behavior of various materials as a function of temperature. A number of researches on thermal properties of wood fiber and polymer composites (WFPCs) have been reported (Tamer and Fauziah, 2009). A number of different methods have been used to investigate thermal properties and vescoelastic properties of wood. One such method is dynamic mechanical thermal analysis (DMTA). This has been used to investigate wood from different trees species. The variations of MFA with the tree ages were studied for the real wood cell wall structure of Acacia mangium using X-ray diffraction (Tamer and Fauziah, 2009). The results of MFA measurements from the eight Acacia mangium trees, 3, 5, 7, 9, 10, 11, 13 and 15-year-old examined in this study showed that differences in MFAs between tree ages were significant. The general trend was for the MFA to be greatest in the young wood of age 3-year-old and decrease gradually with increasing the tree age. This trend has been found for both pith and bark region of the wood samples. It was found that for eight ages of trees examined, the MFA was at its greatest in the sample of 3-year-old, where angle as high as $26.13^{\circ}$ were recorded. The lowest for all eight cases were taken from the pith region were found in tree age 15-year-old where the angle varied from $1.99^{\circ}$ to $0.20^{\circ}$ in the front cell wall direction of the microfibrils. For all cases of the wood samples were taken from the bark region of the eight trees, the results shows that the MFA was its greatest in tree age 3-year-old, were angle as high as $31.62^{\circ}$ were recorded. Tables are numbered with Roman numerals. The lowest MFAs for the same samples were found in 15-year-old of the trees were the angle was $0.47^{\circ}$ in the back cell wall direction of the microfibrils.

Study by (Tamer and Fauziah, 2009) using small angle x-ray scattering technique shows that MFA in Acacia mangium wood increases rapidly as a function of the distance from pith towards the bark in wood models were taken from 10 year-old. The general trend was for the MFA to be lowest near the pith and then to increase gradually towards the cambium. It was found that for the samples taken from 10 year-old trunk, the MFA was at its lowest at a distance $10.0 \mathrm{~mm}$ from the pith centre, where angle as $0.46^{\circ}$ was recorded. The highest MFA for all samples in the trunk was found at the distance $90.0 \mathrm{~mm}$ from the pith where the angle was $14.44^{\circ}$. When a tree is young it needs to be elastic in order to move in the wind. After some decades, however the cells produced by matured trunk cambium have a smaller MFA for stiffness and keeping the trunk upright. By contrast, young woods have to be rather elastic, allowing them to bend. Therefore, MFA need to be larger. The MFA is thus critical to the total mechanical balance of the tree, correct MFAs are essential for its survival. However, the results clearly show that greater variation exists across the distance from pith to bark and between the tree ages. 
Results from the same study show a good inversely relationship between MFA and the $E^{\prime}$ was evidence in Acacia mangium wood of 10-year-old. A general declining trend for all curves of $E^{\prime}$ test is observed when the wood samples go through higher MFA. The only noticeable variation can be detected in the case of MFA about $6.46^{\circ}$. Thus, as the MFA increases the $E^{\prime}$ decreases. It was found that for a decrease in MFA from $14.44^{\circ}$ to $0.46^{\circ}$, the $E^{\prime}$ increased from $4.76 \times 108 \mathrm{GPa}$ to $9.00 \times 108 \mathrm{GPa}$. The results also showed that $E^{\prime \prime}$ was most strongly influenced by MFA under the same experimental conditions. The model suggests that a similar reduction in MFA as outlined above, causes $E^{\prime \prime}$ to increase about 23,146,225.00 GPa. These results supports those of Cave and Walker (1994) who found that wood stiffness and bending strength are negatively affected by large microfibril angle. Cave and Walker (1994) reported that the tensile strength of the tracheid decreasing with increasing MFA in the cell wall. This behave of dynamic-mechanical properties of wood with MFA may be attributed to the effect of MFA on the density of wood. The density of wood impacts the pulping process, energy consumption and is important for pulp yield (Cave, 1997). High density had a positive correlation with tear strength but the effects diminished when position in the tree was taken in to account indicating that it is not the density in itself that is important but ruther the properties of the fibres which are mirrored by the density (Cave, 1976).

Differences in MFA have a profound effect on the properties of wood, in particular its stiffness. The large MFA in juvenile wood confers low stiffness and gives the sapling the flexibility it needs to survive high winds without breaking. It also means, however, that timber containing a high proportion of juvenile wood is unsuitable for use as high-grade structural timber. This fact has taken on increasing importance in view of the trend in forestry towards short rotation cropping of fast grown species. These trees at harvest may contain $50 \%$ or more of timber with low stiffness and therefore, low economic value. Although they are presently grown mainly for pulp, pressure for increased timber production means that ways will be sought to improve the quality of their timber by reducing juvenile wood MFA (Barnett et al., 2004). Glas transition ( $\left.T_{g}\right)$ determined by the onset of the $E^{\prime}$ change and the maximum of $E^{\prime \prime}$ at $\mathrm{MFA}=18.0^{\circ}$.

\subsection{Determination of glass transition of Acacia mangium Wood by Dynamic Mechanical Thermal analyzer (DMTA)}

In this study, the DMTA technique is used in glass transition, $T_{g}$ calculation. The procedures described in several standards and recommendations can result in significantly different values of the same data, as discussed in detail by Yamamoto et al., (1993). This is due, in part, to the fact that $T_{g}$ is a single temperature that represents a range over which the glass transition takes place (Work Item Wk278, 2003). In an effort to simplify the determination of $T_{g}$, it is commonly defined as the maximum of the damping ratio $E^{\prime} / E^{\prime \prime},(\tan \delta)$ or the maximum of $E^{\prime \prime}$. The $T_{g}$ also can be derived from the onset of the change in the slope of $E^{\prime}$ curve (Akay, 1993). A comparison of these calculation techniques is shown in Figures 16, 17 and 18 If $T_{g}$ is used for engineering design, that is the determination of maximal end-use temperatures, there is a strong believe that the conservative estimate of $T_{g}$ is warranted (Wong et al., 1993). Therefore, in this work, one method of $T_{g}$ calculation was based on the 
temperature at which mechanical properties began to be compromised, that is the maximum damping ratio. This method is used to present the glass transition of Acacia mangium wood as a function to the MFA, because this is the method commonly found in the literature. The thermal and mechanical properties of Acacia mangium wood under analysis are presented in Table 3. The values of $T_{g}$ were calculated based on the maximum damping ratio. The results from pith region of the wood trunk are summarized in Table 4.

\begin{tabular}{|c|c|c|c|c|}
\hline MFA ( $\left(^{\circ}\right)$ & $E^{\prime}(\mathbf{G P a})$ & $E^{\prime \prime}(\mathbf{G P a})$ & $\begin{array}{c}\text { Glass transition } \\
\left(\mathbf{C}^{\circ}\right)\end{array}$ & tan $\boldsymbol{~}$ \\
\hline 18.0 & $9.00 \times 10^{8}$ & 55129999 & 102.583 & 0.175 \\
\hline 19.8 & $7.79 \times 10^{8}$ & 46028906 & 103.213 & 0.145 \\
\hline 19.2 & $7.16 \times 10^{8}$ & 48354672 & 92.694 & 0.166 \\
\hline 22.2 & $7.13 \times 10^{8}$ & 45717485 & 88.899 & 0.165 \\
\hline 24.0 & $7.14 \times 10^{8}$ & 44826412 & 99.669 & 0.151 \\
\hline 25.8 & $6.47 \times 10^{8}$ & 45953213 & 84.633 & 0.165 \\
\hline 29.4 & $6.24 \times 10^{8}$ & 42198028 & 84.113 & 0.153 \\
\hline 28.8 & $6.71 \times 10^{8}$ & 37456490 & 83.688 & 0.172 \\
\hline 30.6 & $4.76 \times 10^{8}$ & 31983774 & 83.895 & 0.147 \\
\hline
\end{tabular}

Table 3. Thermal and mechanical properties of Acacia mangium wood at bark region with respect to the MFA. The values of $T_{g}$ were calculated based on the $\tan \delta$.

\begin{tabular}{|c|c|c|c|c|}
\hline MFA $\left(^{\circ}\right)$ & $E^{\prime}(\mathrm{GPa})$ & $E^{\prime \prime}(\mathrm{GPa})$ & Glass transition $\left({ }^{\circ} \mathrm{C}\right)$ & $\tan \delta$ \\
\hline 0.46 & $9.00 \times 10^{8}$ & 55129999 & 146.825 & 0.175 \\
\hline 3.17 & $7.79 \times 10^{8}$ & 46028906 & 103.213 & 0.145 \\
\hline 4.90 & $7.16 \times 10^{8}$ & 48354672 & 92.694 & 0.166 \\
\hline 6.46 & $7.13 \times 10^{8}$ & 45717485 & 88.899 & 0.165 \\
\hline 7.68 & $7.14 \times 10^{8}$ & 44826412 & 99.669 & 0.151 \\
\hline 8.66 & $6.47 \times 10^{8}$ & 45953213 & 84.633 & 0.165 \\
\hline 11.91 & $6.24 \times 10^{8}$ & 42198028 & 84.113 & 0.153 \\
\hline 12.84 & $6.71 \times 10^{8}$ & 37456490 & 83.688 & 0.172 \\
\hline 14.44 & $4.76 \times 10^{8}$ & 31983774 & 83.895 & 0.147 \\
\hline
\end{tabular}

Table 4. Thermal and mechanical properties of Acacia mangium wood at the pith region with respect to the MFA. The values of $T_{g}$ were calculated based on the $\tan \delta$.

The general declining trend for all curves of $E^{\prime \prime}$ test is observed when the wood samples go through higher temperatures. The only noticeable transition can be detected at around 41.173 $\mathrm{C}^{\circ}$ (indicated by an arrow). As it seen in Figure 16, wood sample at MFA $18.0^{\circ}$ have higher $T_{8}$ based on the maximum value of $E^{\prime \prime}$ about $77.64 \mathrm{C}^{\circ}$. No significant difference between the temperatures based on the change of storage modulus is observed. Results also show that, in the case of the temperature based on the $\tan \delta$, a significant different due to the increase of MFA can easily be seen. It was found that $T_{g}$ ranging between $102.583 \mathrm{C}^{\circ}$ at MFA about $18.0^{\circ}$ and $83.895 \mathrm{C}^{\circ}$ at MFA about $30.6^{\circ}$. Figure 17 and Figure 18 shows the determination of $T_{g}$ in 
wood sample at MFA about $19.8^{\circ}$ and $0.46^{\circ}$ based on $E^{\prime \prime}$ and $E^{\prime}$ respectively. Note that the highest value of $T_{g}$ was recorded at MFA about $0.46^{\circ}$ which is $146.825 \mathrm{C}^{\circ}$.

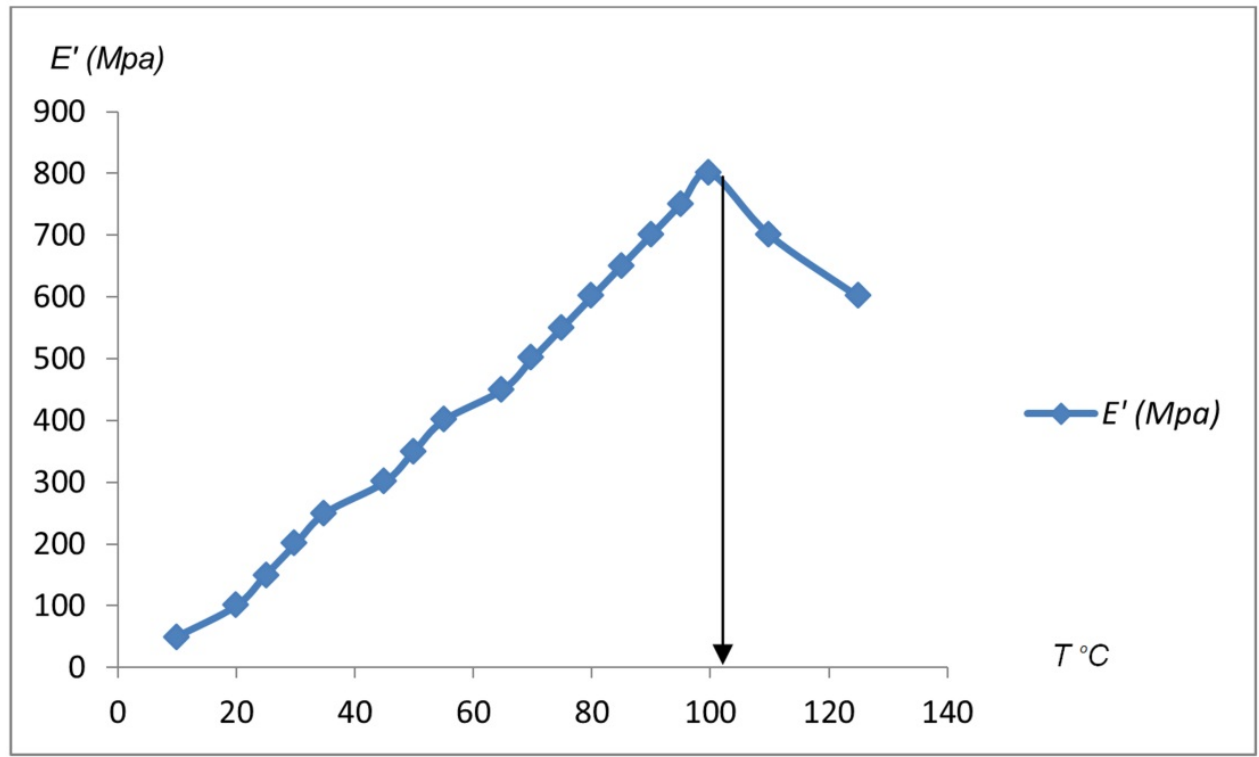

Figure 16. $T_{g}$ determined by the maximum value of $E^{\prime}$ at $\mathrm{MFA}=18.0^{\circ}$. The $T_{g}$ value based on the change of $E^{\prime}=102.583 \mathrm{C}^{\circ}$ while $T_{8}$ based on the maximum of $E^{\prime \prime}=77.647 \mathrm{C}^{\circ}$. The Frequency $=1 \mathrm{~Hz}$.

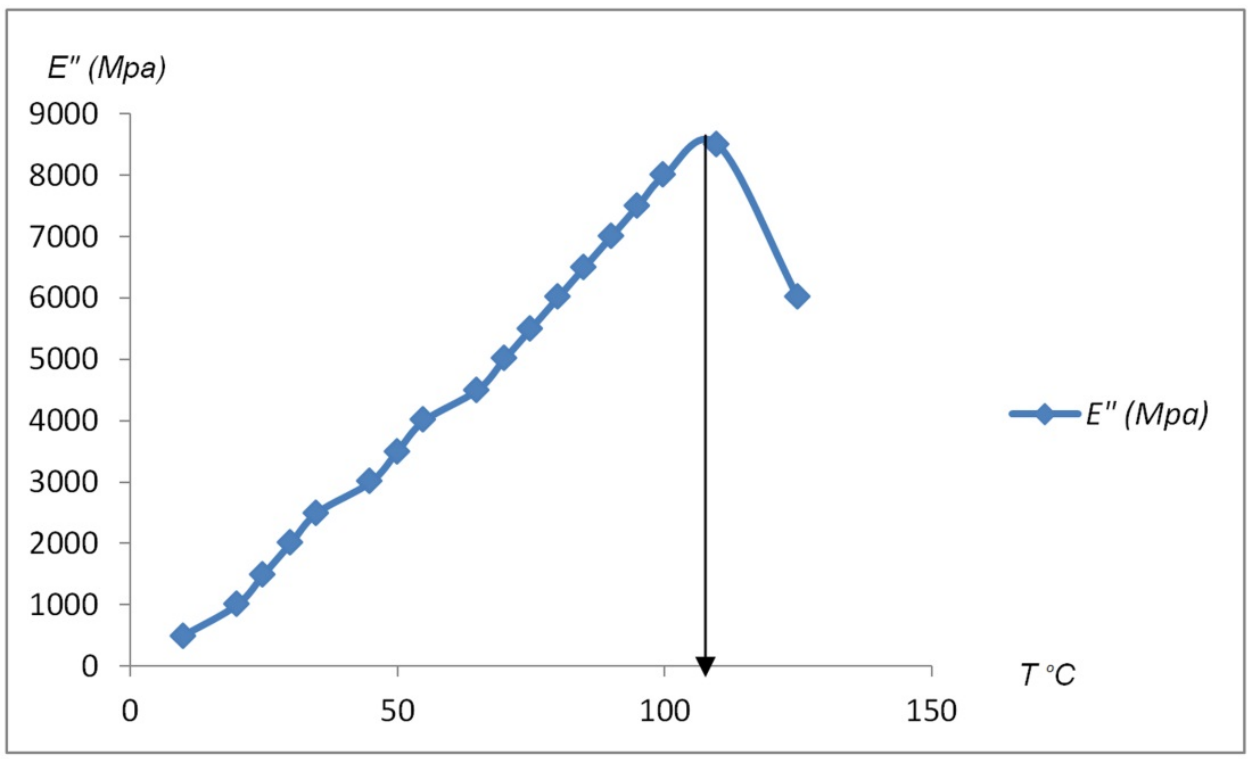

Figure 17. The $T_{g}$ value based on the change of $E^{\prime \prime}=103.213 \mathrm{C}^{\circ}$ at $\mathrm{MFA}=19.8^{\circ}$. Frequency $=1 \mathrm{~Hz}$. 


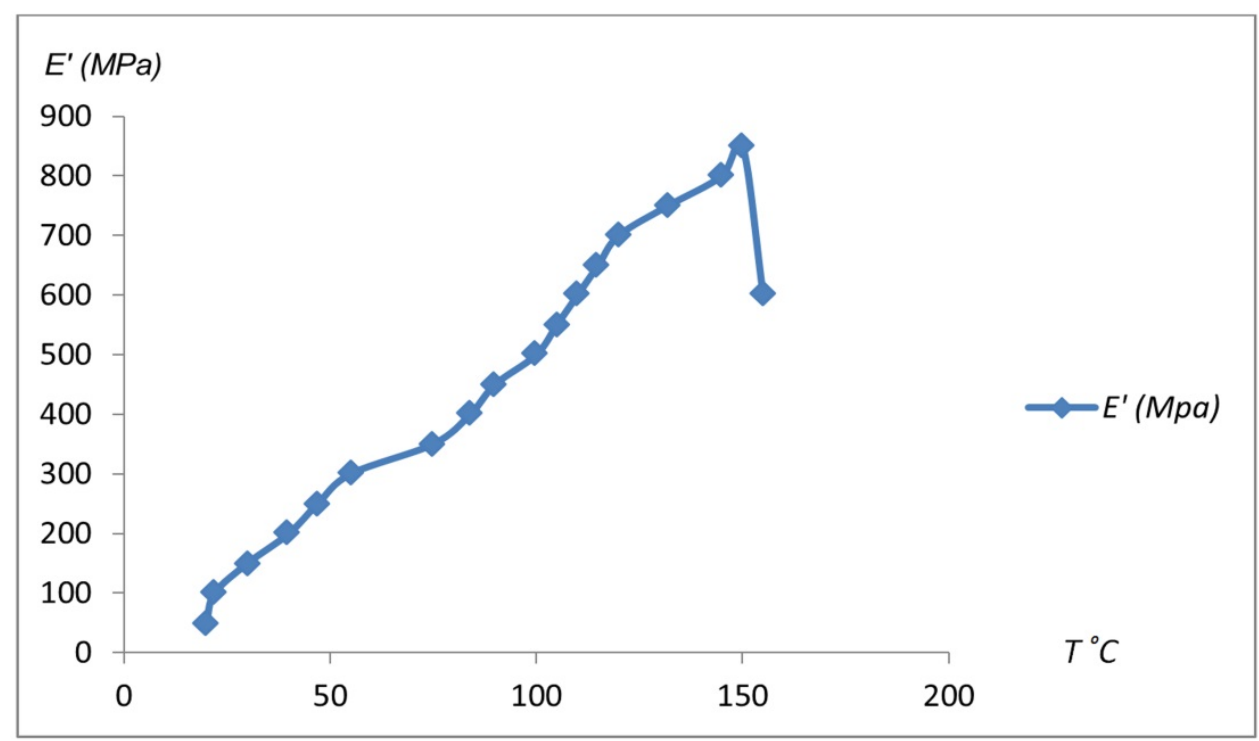

Figure 18. The $T_{g}$ value based on the maximum of $E^{\prime}=146.825 \mathrm{C}^{\circ}$ at MFA $=0.46^{\circ}$. The Frequency $=1$ $\mathrm{Hz}$.

\subsection{The relationship between microfibril angle and storage modulus, loss modulus and glass transition}

The relationship between MFA and the thermal and mechanical properties in Acacia mangium wood was studied in this research. Results show, the storage modulus, $E^{\prime}$ decreased with the increase of MFA. At low MFA about $18.0^{\circ}$, the wood sample shows the highest value of $E^{\prime}$ about $9.0 \times 10^{8} \mathrm{Gpa}$. When the MFA increased over $30.0^{\circ}$ the $E^{\prime}$ decrease to $4.76 \times 10^{8} \mathrm{Gpa}$. A statistical analysis was conducted on these data to determine the relationship between MFA in the cell wall and the thermal and mechanical properties of Acacia mangium wood. Table 5 present the descriptive statistics of the data under analysis. The regression analysis of MFA and $E^{\prime}$ shows that $74 \%$ of variation in storage modulus was explained by MFA. This showed that one regression equation with intercept and slope was required to describe the relationship between MFA and $E^{\prime}$ (Figure 19).

\begin{tabular}{|c|c|c|c|c|c|c|c|c|}
\hline & $\begin{array}{c}\text { N } \\
\text { Statistic }\end{array}$ & Range & Minimum & Maximum & Mean & $\begin{array}{c}\text { Std. } \\
\text { Error }\end{array}$ & Std. & Variance \\
\hline MFA & 9 & 12.60 & 18.00 & 30.60 & 24.20 & 1.57 & 4.7244 & 22.320 \\
\hline Storage & 9 & $4.2 \times 10^{8}$ & $4.8 \times 10^{8}$ & $9.0 \times 10^{8}$ & $6.9 \times 10^{8}$ & $3.8 \times 10^{7}$ & $1.2 \times 10^{8}$ & $1.3 \times 10^{16}$ \\
\hline Loss & 9 & $2.3 \times 10^{7}$ & $3.2 \times 10^{7}$ & $5.5 \times 10^{7}$ & $4.4 \times 10^{7}$ & 2187580 & 6562740 & $4.3 \times 10^{16}$ \\
\hline Damping & 9 & 0.3 & 0.14 & 0.18 & 0.16 & & 0.1226 & 0.000 \\
\hline Trans & 9 & 19.52 & 83.69 & 103.21 & 91.48 & & & 69.442 \\
\hline Valid N & 9 & & & & & & & \\
\hline
\end{tabular}

Table 5. The descriptive statistics of the thermal and mechanical data under Analysis. 


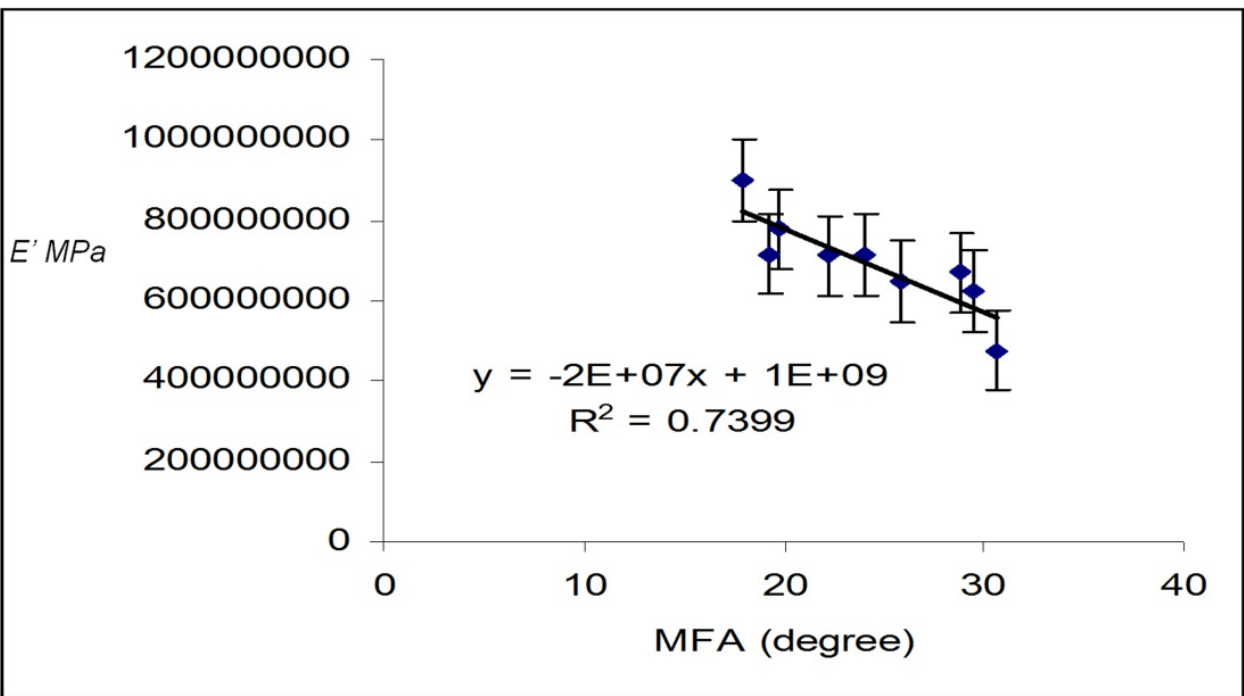

Figure 19. The relationship between MFA and $E^{\prime}$ for wood of 10-year-old.

The relationship between MFA and the loss modulus was discussed. The statistical analysis showed that a straight line fit the data very well. Thus, as the MFA increases the $E^{\prime \prime}$ decreases (Figure 20). The regression analysis of MFA and E" shows that $76.2 \%$ of variation in $E^{\prime \prime}$ was explained by MFA and the analysis of variance shows the impact of MFA on E".

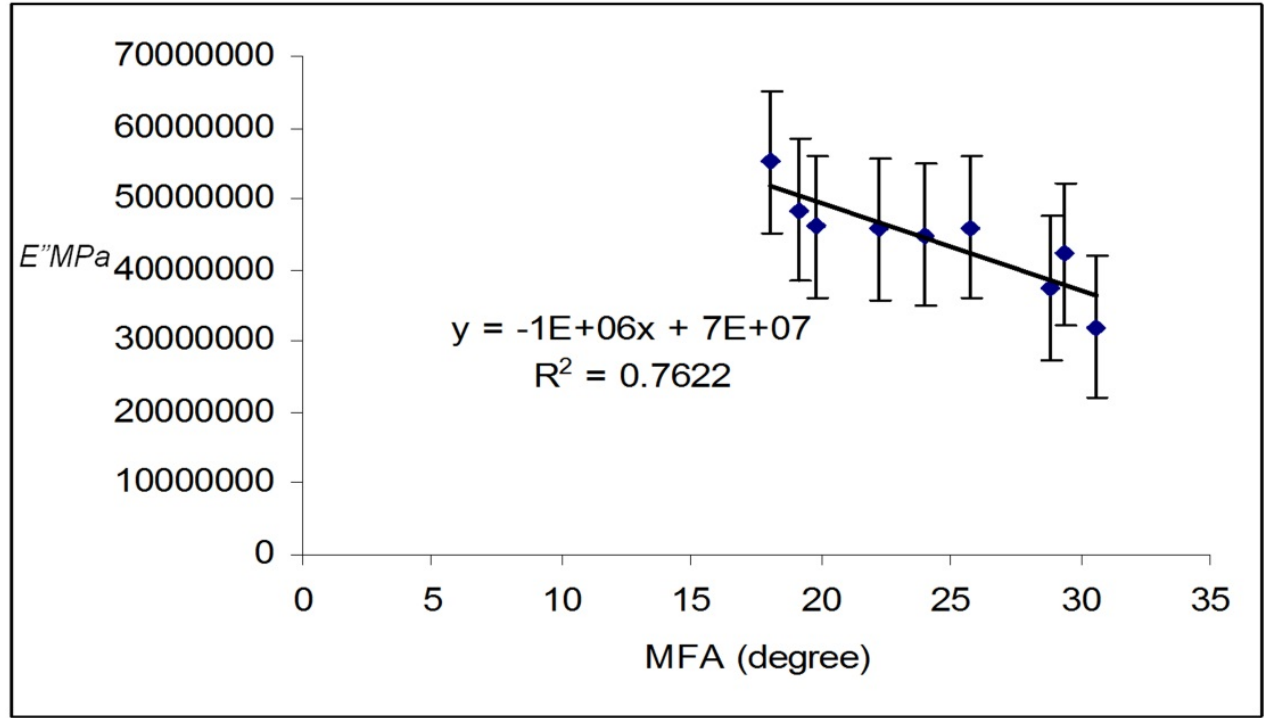

Figure 20. The relationship between MFA and E" in Acacia mangium wood of 10- year-old. 


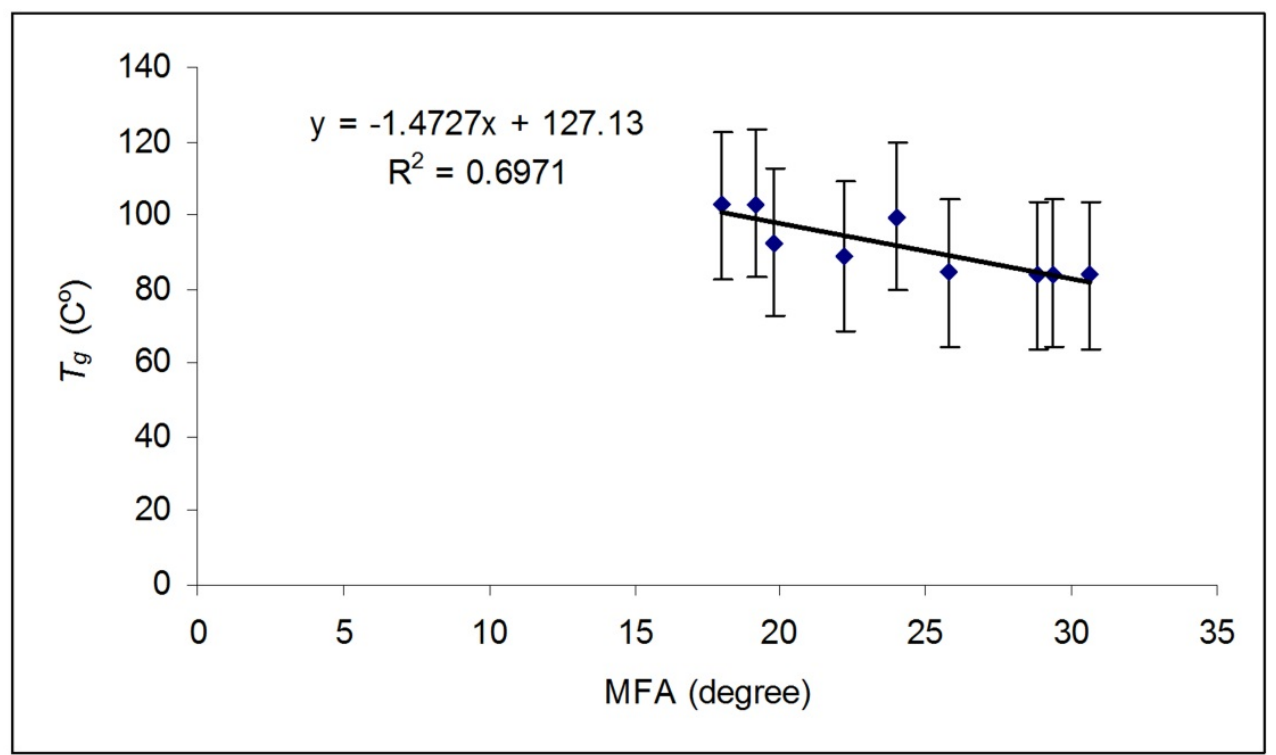

Figure 21. The relationship between MFA and $T_{8}$ in Acacia mangium wood of 10 - year-old.

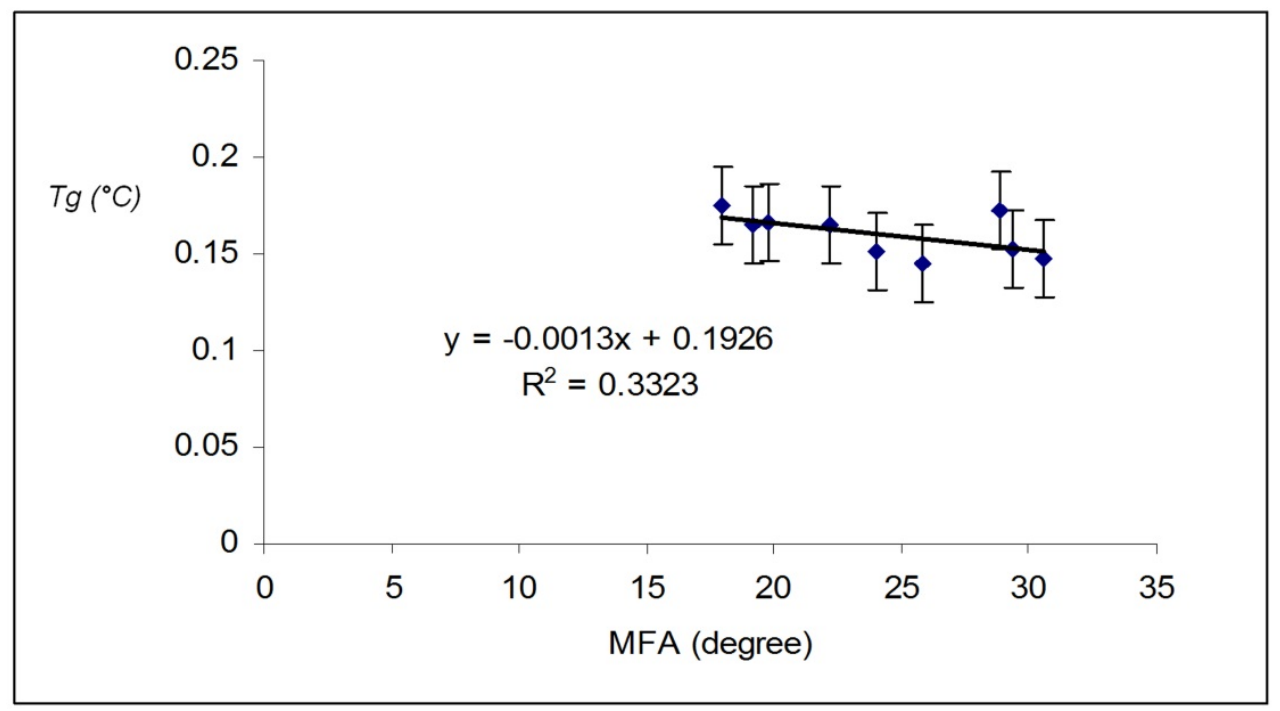

Figure 22. The variation of MFA with tan $\delta$ in Acacia mangium wood of 10-year-old.

The effect of MFA on the glass transition is studied in this research. Figure 21 present the relationship between MFA and $T_{g}$. A similar trend is seen for both $E^{\prime}$ and $E^{\prime \prime}$ with a noticeable reduction in the value of $\mathrm{R}^{2}$ of the graph. As a comparison with the regression 
analysis of MFA and E", where $76.2 \%$ of variation in $E^{\prime \prime}$ was explained by MFA, the MFA accounts for $69.7 \%$ of variation in $T_{g}$ (Figure 21). In contrast to the regression analysis of MFA and E", no clear relationship between MFA and the damping ratio tan $\delta$ is observed (Figure 22). Inversely correlation was evident between $T_{g}$ and MFA in Acacia mangium wood.

As a result, the mechanical properties of Acacia mangium wood can be expected to weaker with high MFA. Glass transition in highly crystalline polymers is difficult to identify (Barnett et al., 2004). This is true because in such cases $T_{g}$ is a minor event, masked by crystallinity, and because crystalline polymers frequently have multiple transitions arising from relaxations associated with amorphous phase, or both. The effect of MFA on the glass transition was discussed in this study. $T_{g}$ was calculated based on the temperature at which mechanical properties began to be compromised, that is the maximum damping ratio (Tamer and Fauziah, 2009).

\section{Conclusion}

In this work, the variations of MFA with the tree ages were studied for the real wood cell wall structure of Acacia mangium using X-ray diffraction. The results of MFA measurements from the eight Acacia mangium trees, 3, 5, 7, 9, 10, 11, 13 and 15-year-old examined in this study showed that differences in MFAs between tree ages were significant. The general trend was for the MFA to be greatest in the young wood of age 3-year-old and decrease gradually with increasing the tree age. This trend has been found for both pith and bark region of the wood samples. It was found that for eight ages of trees examined, the MFA was at its greatest in the sample of 3-year-old, where angle as high as $26.13^{\circ}$ were recorded. The lowest for all eight cases were taken from the pith region were found in tree age 15year-old where the angle varied from $1.99^{\circ}$ to $0.20^{\circ}$ in the front cell wall direction of the microfibrils. For all cases of the wood samples were taken from the bark region of the eight trees, the results shows that the MFA was its greatest in tree age 3-year-old, were angle as high as $31.62^{\circ}$ were recorded. Tables are numbered with Roman numerals. The lowest MFAs for the same samples were found in 15-year-old of the trees were the angle was $0.47^{\circ}$ in the back cell wall direction of the microfibrils. Results shows that MFA in Acacia mangium wood increases rapidly as a function of the distance from pith towards the bark in wood models were taken from 10 year-old. The general trend was for the MFA to be lowest near the pith and then to increase gradually towards the cambium.It was found that for the samples taken from 10 year-old trunk, the MFA was at its lowest at a distance $10.0 \mathrm{~mm}$ from the pith center, where angle as $0.46^{\circ}$ was recorded. The highest MFA for all samples in the trunk was found at the distance $90.0 \mathrm{~mm}$ from the pith where the angle was $14.44^{\circ}$. Obviously, the MFA has a strong correlation with the wood quality as well as with the physiomechanical function of tree (Cave, 1997)]. When a tree is young it needs to be elastic in order to move in the wind. After some decades, however the cells produced by matured trunk cambium have a smaller MFA for stiffness and keeping the trunk upright. By contrast, young woods have 
to be rather elastic, allowing them to bend. Therefore, MFA need to be larger. The MFA is thus critical to the total mechanical balance of the tree, correct MFAs are essential forits survival. However, the results clearly show that greater variation exists across the distance from pith to bark and between the tree ages. Effect of MFA on the storage modulus, loss modulus and glass transition of Acacia mangium wood is discussed in this study. Results show a good inversely relationship between and the $E^{\prime}$ was evidence in Acacia mangium wood of 10-year-old. A general declining trend for all curves of $E^{\prime}$ test is observed when the wood samples go through higher MFA.

The only noticeable variation can be detected in the case of MFA about $6.46^{\circ}$ (Table 4 ). Thus, as the MFA increases the $E^{\prime}$ decreases. It was found that for a decrease in MFA from $14.44^{\circ}$ to $0.46^{\circ}$, the $E^{\prime}$ increased from $4.76 \times 108 \mathrm{GPa}$ to $9.00 \times 108 \mathrm{GPa}$. The results also showed that $E^{\prime \prime}$ was most strongly influenced by MFA under the same experimental conditions. The model suggests that a similar reduction in MFA as outlined above, causes $E^{\prime \prime}$ to increase about 23,146,225.00 GPa. These results support those of Cave and Walker (1994) who found that wood stiffness and bending strength are negatively affected by large microfibril angle. Cave (1976) and Mary Treacy (2001) reported that the tensile strength of the tracheid decreasing with increasing MFA in the cell wall. This behaves of dynamic-mechanical properties of wood with MFA may be attributed to the effect of MFA on the density of wood. The density of wood impacts the pulping process, energy consumption and is important for pulp yield (Donaldson, 1993). High density had a positive correlation with tear strength but the effects diminished when position in the tree was taken in to account indicating that it is not the density in itself that is important but the properties of the fibres which are mirrored by the density (Cave, 1976). Farther more has been reported that these two properties have been successfully combined to predict the dynamic-mechanical properties of small specimens (Cave, 1997).

\section{Author details}

Tamer A. Tabet

School of International Tropical Forestry, University Malaysia Sabah, Kota Kinabalu, Sabah, Malaysia

Fauziah Abdul Aziz

Physics Department, Centre for Defence Foundation Studies, National Defence Universiti of Malaysia, Kem. Sg. Besi, Kuala Lumpur, Malaysia

\section{Acknowledgement}

We greatly appreciate the professional co-operation and assistance of Universiti Malaysia Sabah. We also wish to thank Universiti Putra Malaysia in accessing and using the X-Ray

${ }^{*}$ Corresponding Author 
diffraction equipment. Finally, we would like to thank fully Universiti Kebangsaan Malaysia for the professional cooperation.

\section{References}

[1] Addis, A., Buchanan, B.H. \& Walker, J.C.F. 1995. Stiffness and Tensile Strength Variation Within and Between Radiata pin Trees. Journal of Institute of Wood Science 13(5):513-518

[2] Andersson, A.D. 2006. A Study of the Nanostructure of the Cell Wall of the Tracheids of Conifer Xylem by X-Ray Scattering. University of Helsinki, Report Series in Physics. HU-PD 135: 18-25.

[3] Arntzen and Charles J. 1994. Encyclopedia of Agricultural Science. Orlando, FL; Academic Press. Vol 4. Pp 549-561.

[4] Barnett J.R., Victoria A. and Bonham. 2004. Cellulose microfibril Angle in the Cell Wall of Wood Fibres. Biological Reviews Journal. Vol. 79 Issue 2, pages461-471.

[5] Bertaud, F. \& Holmbom, B. 2004. Chemecal Composition of Earlywood and Latewood in Norway spruce Heartwood, Sapwood and Transition Zone Wood. Wood Science and Technology, 38 (4):245-256.

[6] Batchelor, W.J., Conn, A.B. \& Barker, I.H. 1997. Measuring the Fibril Angle of Fibres Using Confocal Microscopy. Appita J. 50:377-380.

[7] Bergander, A., Brändström, J., Daniel, G. \& Salmén, L. 2002. Fibre Angle Variability in Earlywood of Norway spruce Using Soft Root Cavities and Polarization Confocal Microscopy. J. Wood Sci, 21(3): 209-211.

[8] Boyd, J.D. 1977. Interpretation of X-Ray Diffractograms of Wood for assessments of Microfibril Angles in Fibre Cell. Wood Science and technology 11(2): 93-114

[9] Brändström, J. 2002. Morphology of Norway spruce Tracheids with Emphasis on Cell Wall Organization. Department of Wood SLU. Sueciae. Silvestria Vol. 237: 403-415.

[10] Butterfield, B.J. 1980. Handbook of Three-Dimensional Structure of Wood. $2^{\text {nd }}$ ed. London, United kingdom: Chapman and Hall Publishers, pp. 99 -115.

[11] Cave, I.D. 1966. X-Ray Measurement of Microfibril Angle. For. Prod. J. 44: 37 - 4.

[12] Cave, I.D. 1997a.Theory of X-Ray Measurement of Microfibril Angle in Wood. Part 1. The Condition for Reflection. X-Ray Diffraction by Materials with Fibre Type Symmetry. Wood Science and Technology, 31 (3): 143-152.

[13] Cave, I.D. 1976. Modeling the Structure of the Softwood Cell Wall for Computation of Mechanical Properties. Wood Science and Technology. 10:19-28.

[14] Cave, I.D. \& Walker J.F.C. 1994. Stiffness of Wood in Farown Plantation Softwood: The Influence of Microfibril angle. Forest Product Journal, 44 (5): 43-48.

[15] Cown, D.J. \& Clement, B.C. 1983. A Wood Densitometer Using Direct Scanning with XRay. Wood Science and technology 17: 91-99. 
[16] Dadswell, H.E., Nicholls, J. W. P. and Echols R. M. 1959. Assessment of Wood Qualities for Tree Breeding in Pinus elliottii from Queensland. Queensland, Australia: Div. of For. Prod, 12 (4): 98-112.

[17] Donaldson, L.A. 1991. The Use of Pit Apertures as Windows to Measure Microfibril Angle in Chemical Pulp Fibres. Wood and Fibre Science. 23: 290-295.

[18] Elliot G.K. 1970. Handbook of Wood Density in Conifers. Technical Communication No.8, Commonwealth Forestry Bureau: Oxford, England. pp. 88-101.

[19] Hakan, H., Jemes W., Evans, R. \& Steve, P. 1998. Influence of Cambial Age and Growth Conditions on Microfibril Angle in Young Norway spruce and Picea abies. Holzforschung. 52: 573-581.

[20] Haygreen, J.G. \& Bowyer J.L. 1996. Forst Product and Wood Science (An introduction). $3^{\text {rd }}$ edition, PP. 490-513.

[21] Harris, J.M. \& Meylan, B.A. 1965. The Influence of Microfibril Angle on Longitudinal and Tangential Shrinkage in Pinus radiate. Holzforschung 19:144-153.

[22] Latif, M.A., \& Habib, M.A. 1994. Biomass Tables for Acacia mangium Grown in the Plantation in Bangladesh. J. Trop. For. Sci. 7 (2): 296-302.

[23] Meylan, B.A. 1967. Measurement of Microfibril Angle by X-Ray Diffraction, Forest Prod. J. 17: 15-58.

[24] Meylan, B.A. 1972. The Influence of Microfibril Angle on the Longitudinal ShrinkageMoisture Content Relationship. Wood Science and Technology 6: 293-301.

[25] Reiterer, A. Lichtenegger, H., Tschegg S. \& Fratzl 1999. Experimental Evidence for Mechanical Function of the Cellulose Microfibril Angle in Wood Cell Walls. Philosophical Magazine A 79 (9): 2173-2184.

[26] Svergun, D.I. \& Stuharmann H.B. 1991. New Developments in Direct Shape Determination from Small-Angle X-Ray Scattering, 2. Theory and Model Calculations. Acta. Cryst. A 47: 736-744.

[27] Tamer A. and Fauziah Aziz. 2009. Influence of Microfibril Angle on Thermal and Dynamic-Mechanical Properties of Acacia mangium Wood Using X-Ray Diffraction and Dynamics-Mechanical Test. Journal of Nuclear and Related Technologies. Vol. 6, No. 1. P.P 71-86 (Special edition).

[28] Tsoumis, G. 1992. Science and Technology of Wood Structure, Properties and Utilization. New York: Van Nostrand Reinhold: London; Chapman and Hall, PP 494-501.

[29] Jakob, H. F., Tschegg, S. E. and Fratzl, P. 1994. Size and Arrangement of Elementary Cellulose Fibril in wood Cells: A small-angle X-ray scattering study of Picea abies, J. Struct. Biol. 113: 13-22.

[30] Jean-Paul Joseleau, Takanori Imai and Katsushi Kuroda Katia Ruel. 2004. Detection in situ and characterization of lignin in the G-layer of tension wood fibres of Populus deltoids. Planta (2004) 219: 338-345.

[31] Jozsa, L.A. \& Middleton G.R. 1994. A Discussion of Wood Quality Attributes and their Practical Implications. Forintek, Canada special publication No. SP-34. pp. 113-123. 
[32] Wilson, B.F. \& Archer R.A. 1979. Three Designs: Some Biological Solutions to Mechanical Problems. Forestry J., 9: 293-298.

[33] Yamamoto H., Okuyama T. \& Yoshida M. 1993. Method of Determining the Mean Microfibril Angle of Wood Over a Wide Range by the Improved Cave's Method. Mokuzai aaagkkaishi 39: 11-1.

[34] Zobel, B.J. 1961. Inheritance of Wood Properties in Conifers. Silvae Genet. 10: 65-70. 